\title{
RÓMAI ÚT ÉRD HATÁRÁBAN
}

\author{
VARGA GÁBOR*
}

The article deals with the road section between Érd and Százhalombatta. Earlier publications proposed that the road section was paved in modern times, but the latest publication dated it to the Roman Age. Thus we collected all earlier data to investigate the age of the road section.

Keywords: Roman Age, limes, road, Érd, Százhalombatta

\begin{abstract}
A közlemény az Érdés Százhalombatta között húzódó útszakasszal foglalkozik. A szakirodalomban már korábban is felmerült, hogy az utat az újkorban lekövezhették, de legutóbb az út római kori datálása mellett foglaltak állást. Ezért a kérdést a lelőhelyre vonatkozó adatok összegyüjtésével és közreadásával vizsgáljuk tovább.
\end{abstract}

Kulcsszavak: római kor, limes, út, Érd, Százhalombatta

A lelóhely az Érd déli határától egyenes vonalban Százhalombatta felé vezető földút (1. kép), ${ }^{1}$ melynek hivatalos neve Római út. ${ }^{2}$ A kutatás az út nyomvonalát a római korra datálja, és a limesúttal azonosítja, mivel egyenes nyomvonala déli irányban meghosszabbítva Matrica táborának északi kapujához vezet. A szakirodalom úgy véli, hogy északi irányban az út északkelet felé fordult, és a mai Mély út vonalán jutott le a löszfennsíkról a Duna partjára. Az út kövezett felszínét a római korra vagy az újkorra keltezték.

Szabó Máté 2012-ben szondázó ásatást végzett a lelőhely érdi szakaszán. Kutatásának eredményét példaértékú módon tette közzé 2014-ben. ${ }^{3}$ Beszámolója végén arra a megállapításra jut,

* A kézirat érkezett: 2016. március 21.

* Varga Gábor. H-1044 Budapest, Fóti út 17., varga.gabor80@ gmail.com

1 MRT 7, 102-103, 9/25. lelőhely és 240-241, 27/10. lelőhely.

2 Ezért a cikkben „Római út” megjelölés alatt nem „római kori út" értendő.

3 SZABÓ 2014. hogy az általa feltárt köves útfelszín egyértelmúen a római korra datálható. Az összefoglalás vitathatatlan magas színvonala ellenére is érdemes a lelőhelyre vonatkozó korábbi adatokat tüzetesen megvizsgálni, mivel az útfelszín újkori datálása továbbra sem kizárható.

\section{Az Érd és Százhalombatta közötti Római út levéltári és térképészeti adatai}

Feltehetően ezt az utat említi 1244-ben „viam publicam"-ként egy oklevél. ${ }^{4}$

1282-1285 között összeállított múvében Kézai Simon $^{5}$ - majd Kézai nyomán a Képes Krónika, ${ }^{6}$ Thuróczy János, ${ }^{7}$ Bonfini $^{8}$ és Oláh Miklós ${ }^{9}$ „stratam"-ként utalt az útra. Bár az út említését

4 MNL OL Q 163 Dl. 73615. L. GYÖRFFY 1998, 570; BAKÁCS 1982, 38., 49. sz.

5 SRH I. 150, 9. caput.

6 SRH I. 260, 9. caput.

7 THURÓCZY 1985, 36, 13. caput: "stratam communem”.

8 Bonfini 1936, 66, I. tized 3. könyv 32.: „celebri via”.

9 OLÁH 1938, 36-37, 2.1. caput: „viam publicam”. 


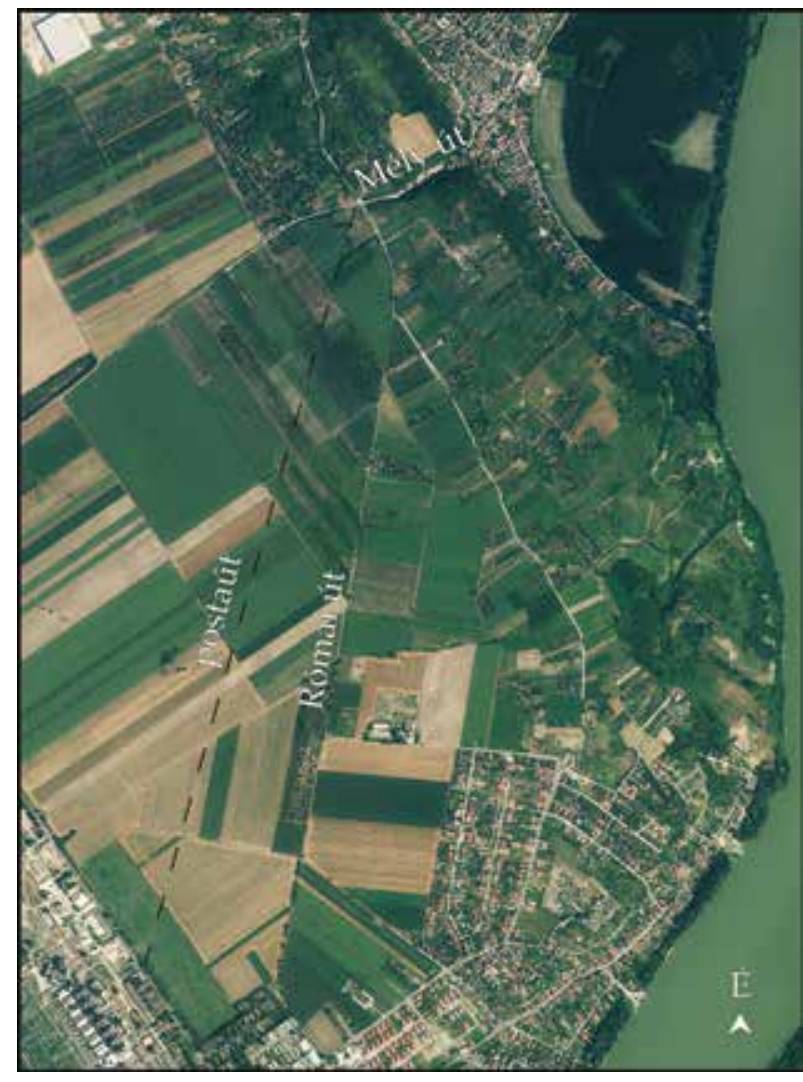

1. kép. A lelőhely Érd és Százhalombatta között

Fig. 1. The site between Érd and Százhalombatta

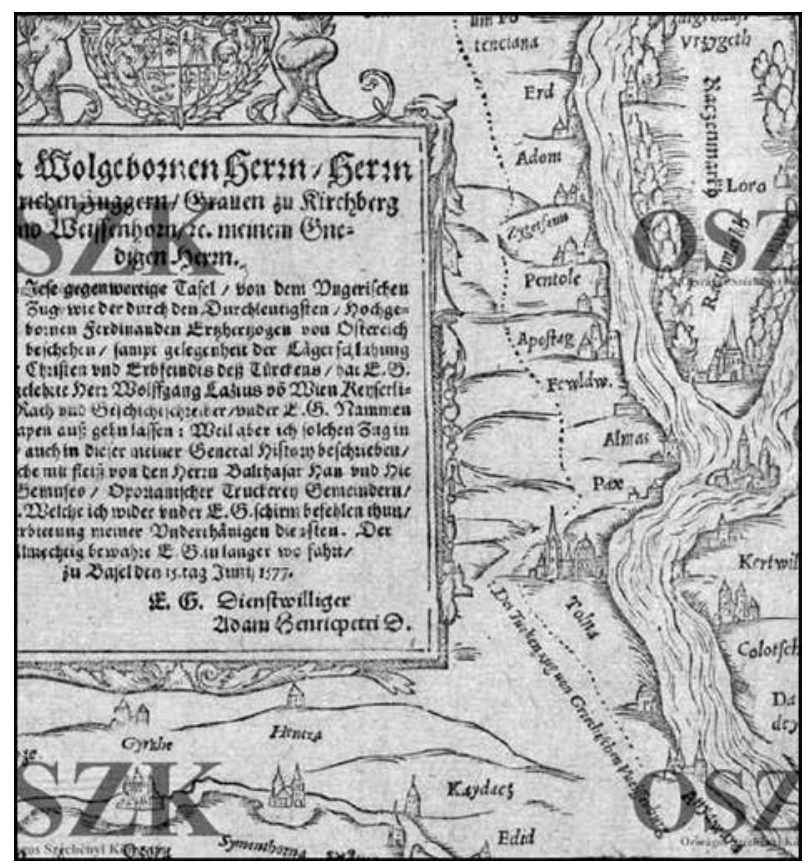

2. kép. Az 1556. évi török hadjáratot ábrázoló térkép részlete, 1577 (OSZK TE 122)

Fig. 2. Detail from the map of the Turkish campaign in 1566; 1577 (OSZK TE 122)

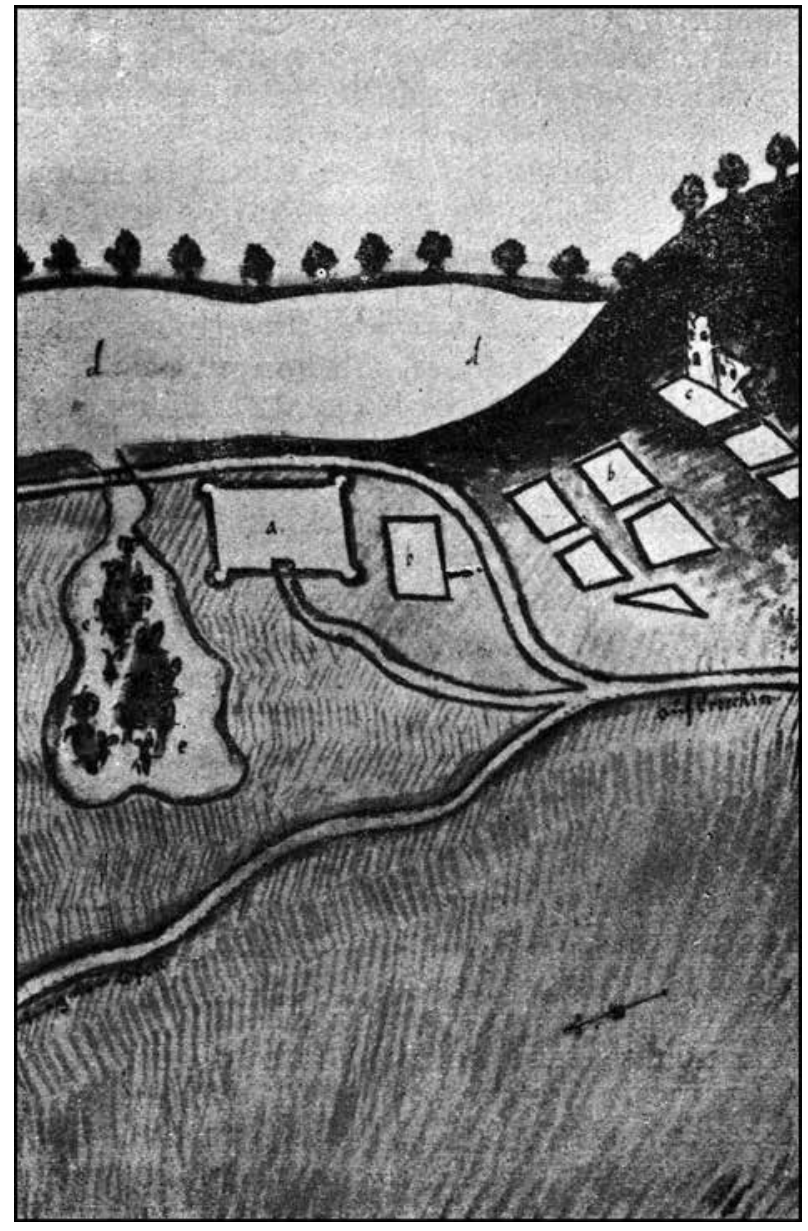

3. kép. Ottendorf Henrik Érdet ábrázoló rajza, 1663 (HERMANN 1943, 38.)

Fig. 3. Henrik Ottendorf's drawing of Érd, 1663 (HERMANN 1943, 38)

mesés történetbe ágyazta, a bronzkori halomsíros temető („Százhalom”) és a bronzkori tell település és vaskori sánc („Potentiana”) említése miatt a lelőhely egyértelmúen azonosítható a szöveghellyel.

1526-ban II. Lajos Mohács felé tartva Érden szállt meg. ${ }^{10} \mathrm{~A}$ későbbi szakirodalom ${ }^{11}$ állításával ellentétben csak az biztos, hogy Érden keresztül vezetett a Mohácsot is érintő út, de az nem, hogy ekkoriban is az egykori limesút nyomvonalán haladt.

A török korból elenyészők az útra vonatkozó adataink. Nem tett róla említést sem Evlia Cselebi, sem Hans Dernschwam, és Marsigli sem ábrázolta térképein. Egy 1577-ben készült térképen ${ }^{12}$ pontozott vonal halad a Dunával párhuza-

10 IstVÁNFFY 210., VIII. könyv; Bél 1977a, 111-112; BÉl 1977b, 162-163.

11 KáROLY 1901, 116.

12 OSZK TE 122; PAulovics 1927, 7., 2. kép. 

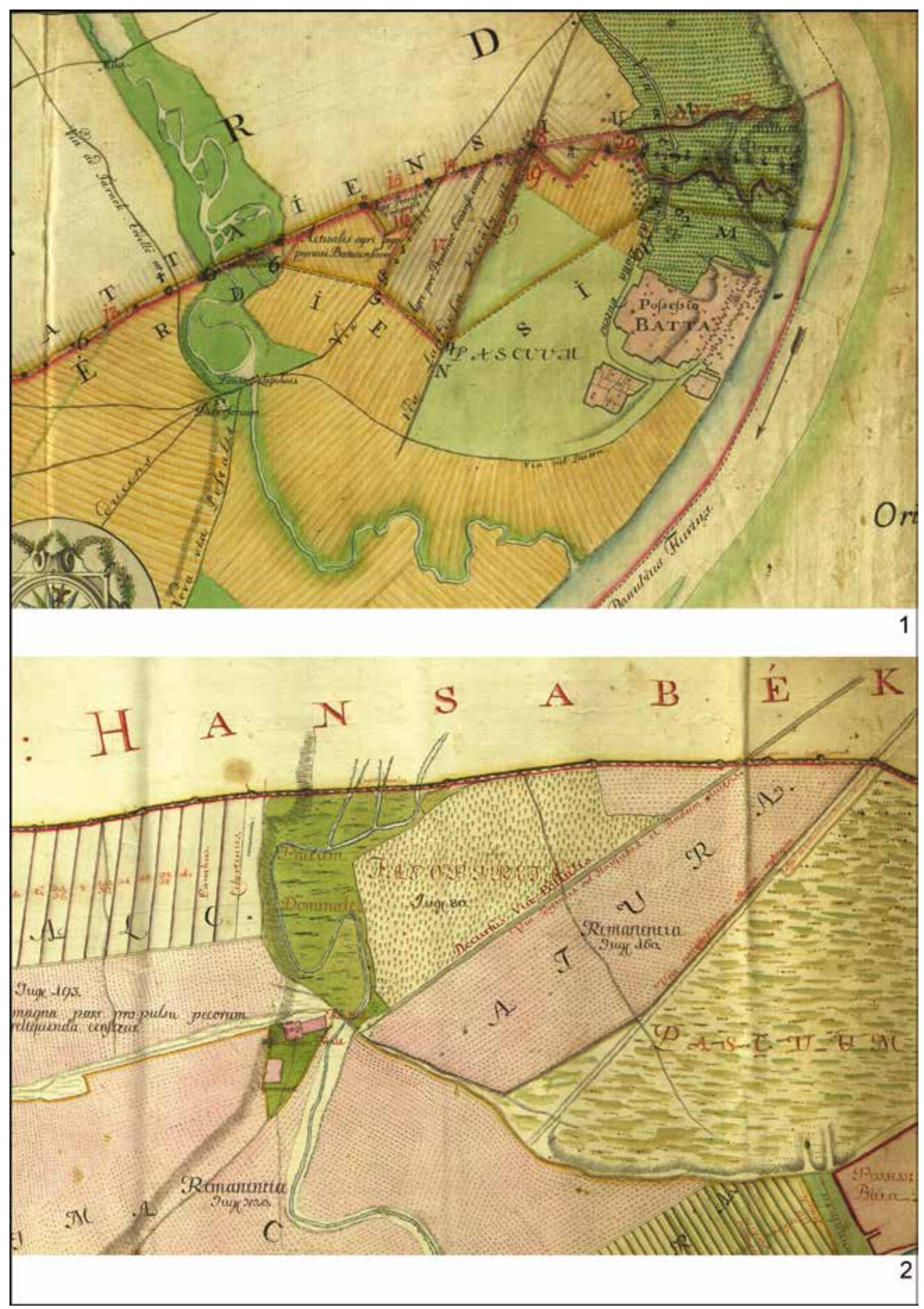

4. kép. Balla Antal Százhalombattát ábrázoló térképének részlete. 1: 1768 (MNL OL S 169, No. 5); 2: 1773 (MNL OL S 169, No. 10)

Fig. 4. Details from Antal Balla's map of Százhalombatta. 1: 1768 (MNL OL S 169, No. 5); 2:1773 (MNL OL S 169, No. 10) 
mosan, "Des Turken zug von Griechischen Vueissenburg" felirattal jelölve (2. kép). Csak feltételezhetjük, hogy itt is ugyanezt az utat jelölheti a térkép, mivel az útvonal elkerüli a településeket. 1663-ban Ottendorff Henrik úgy ábrázolja az utat, mint ami elkerüli Érdet (3. kép). Ennek némileg ellentmond szöveges leírása: „A vidék Buda és Hamzabég között Buda alatt eléggé hegyes azután majdnem fél mérföldön át lapos, sík területre ér az ember, amelyen a nagyvezér táborozott. Azután ismét egy hegyen kell átjutni, mely Hamzabégig fokozatosan síkságba megy át; itt már köröskörül tiszta, sík területet lát az ember. De röviddel a falu mögött, Ercsi felé újra egy eléggé magas hegy fekszik, mely jobbfelé messze kinyúlik."13 Ez utóbbi mondat valószínúleg az Érdi-fennsíkra felvezető mai Mély útra vonatkoztatható.

1730-1750 között készült Mikoviny Sámuel Fejér megyét ábrázoló térképe. ${ }^{14}$ Ezen Érd térségében két utat ábrázolt, az egyiket „via postalis”, a másikat „via regia lapidibus strata per regem Ladislaum facta" felirattal jelölte. Utóbbi dél felé Kisapostag előtt véget ér (itt egy romot is ábrázol a térkép), ezért felhagyott útként értelmezhető. Az útvonal északi vége Érd déli határában beköt a postaútba. Arra nézve, hogy melyik László királyhoz kötötte az út építését és miért, nincs adatunk. ${ }^{15}$

1746-1749 között állította össze Bél Mátyás a Notitia Fejér megyéről szóló kéziratát. Noha Mikoviny térképe minden valószínúség szerint rendelkezésére állt, és bár számos más régészeti emlékről tett említést, a római kori út maradványairól nem emlékezett meg. ${ }^{16}$

1743-ban egy érdi határper során „Király kőves úttya"-ként említik a római kori út maradványait. ${ }^{17}$ Ugyanitt szintén szerepel az "Ercsibül Budára vezetö Pósta ut" is.

Balla Antal 1768-ban készített, Százhalombattát ábrázoló térképe a postautat (,Via Postalis") és a római kori utat (,Via Lapidosa Király ut dicta") is feltünteti (4. kép 1). ${ }^{18}$

Ugyanő 1773-ban készített térképén a postutat "Via Postalis ad Hansabek et Budum (sic!) ducens,"

13 HeRMANN 1943, 38.

14 BENDEFy 1976, II. 6. térképlap; VIsy 2000, 60.

15 1808-ban Iváncsánál Szent László útnak hívták: CIL III 3721; POLGÁr 1932, 6.

16 BÉL 1977a, 111-112.; BÉL 1977b, 163-164.

17 MNL OL P 1341 lad. 23. fasc. 30. No. 4, 2. lap, 4-5. kérdés és 4. lap, az 1. tanú 4. kérdésre adott válasza; MRT 7, 240, 27/10. lelőhely; VISY 2000, 61. FML Acta Locorum - Érd, 2-4., 6. és 8-9. tanú 4. kérdésre adott válasza; NAGY 1972, 236., Batta címszó 2. pont.

18 MNL OL S 169, No. 5; KovÁcs 1999, 59-60, T. XXXV; KovÁcS 2000, 8-9, Fig. 1-2.; KovÁCs 1999, 59. és KovÁcs 2007, 219, 39. jegyzet „OL P 590 17. cs. 17. f."-ként utal erre a térképre. a római kori utat "Via antiquissima strata reliquia” felirattal jelzi (4. kép 2). ${ }^{19}$

Az 1783-ban készült első katonai felmérés nem ábrázolja a római kori út maradványát, csak a postautat (5. kép 1). ${ }^{20}$

Egy 1783. évi kéziratos térképen a postautat 8. szám jelöli (5. kép 2). ${ }^{21}$ Vele párhuzamosan halad a Római út, feltehetően erre vonatkozik a 15. szám jelölése, bár valójában egy másik útra írták. A szám magyarázata a térképen: „Via Kradlicsin put dicta." A „Kradlicsin” szó jelentését nem ismerem, talán a 'tolvaj' jelentésú szerb/horvát „kradljivac” szóval állhat kapcsolatban.

Benyovszky Imre 1795. évi, Százhalombattát ábrázoló térképén a postautat "Via regia Postalis Budensis," a római kori utat "Agger antiquus Kiraly Uttya vulgo Kraljev put nuncupatus" felirattal jelöli (5. kép 3). ${ }^{22}$ A „,Kraljev” szerb szó, jelentése: királyi. Az útszakasz déli végét szaggatott vonal jelöli, telekhatárként sem funkcionál.

1813-ban Szapáry János, Érd birtokosa javasolta a postaút helyett a "Római út” felújítását: „Elölülő M(é)l(tósá)gos Al Ispán Ur felfedezte, hogy M(é)l(tósá)gos Fő Ispán Ur Ö Excellentiája nem régiben közölni méltoztatott véle Gróf Szápáry János Ur Ö Excellentiájának panaszait, mellyeket az iránt tesz, hogy előszőr a' Budáról Ertsin keresztül menő országút igen rosz karban tartatik, hogy $2^{\text {or }}$ az Ertsi jobbágyság(nak) Urbariomi Földein lévő vízállásokat tsatornák segítségével letsapoltatni szándékozván, $e^{\prime}$ végben tett folyamodására $a^{\prime} N$ (emes) V(árme)gye segítséget nem nyujtott; hogy $3^{\text {or }}$ ellene Jankovich Miklos Ur(nak) egy hetven ezer F(orin)tos kötelezölevele, a' kőtés(nek) világos tartalma is félrevettetvén, mely szerént ezen tőkepénz tsak más negyven ezer forint után jegyeztethetik az adosságok könyvébe, hibásan,ésazőhitelé(nek) nevezetes kárával intabuláltatott; ezekre nézve tehát $a^{\prime}$ tisztelt Fő Ispán Ur azon utmutatást méltoztatott kegyesen adni, hogy az elsó és második panaszt mivolta egy kiküldendó választság által, mellyhez a' panaszolkodó M(é)l(tósá)gos Uraság egy Kormánybeli Földméröt is szándékozik kiszollittatni, megvizsgáltassék, és a' két tárgy(nak) miképpen eszközölhető eligazitásáról, jelesen pedig, mivel $a^{\prime}$ dunának áradásai az emlitett posta útnak igazításán gyakran igen költségessé teszik a' panaszkodó Grófnak kivánsága szerént a'ról is, hogy az Érdi, Battai, és Ertsi határokban Adony felé látható régi Római útnak nyomdoki, és fekvése megtekéntetvén, mellyik út(nak) tsinálása, és megtartása volna az adózó nép(nek) kevesebb terhére, vélemény adattassék, a' mi pedig $a^{\prime}$ hibá-

19 MNL OL S 169, No. 10.

20 Colonne XIII, Sectio 22.

21 OSZK TF 4

22 MNL OL S 113, No. 1 és S 156, No. 1; KovÁCs 1999, T. XXXVI; KovÁCs 2000, Fig. 3-4. 

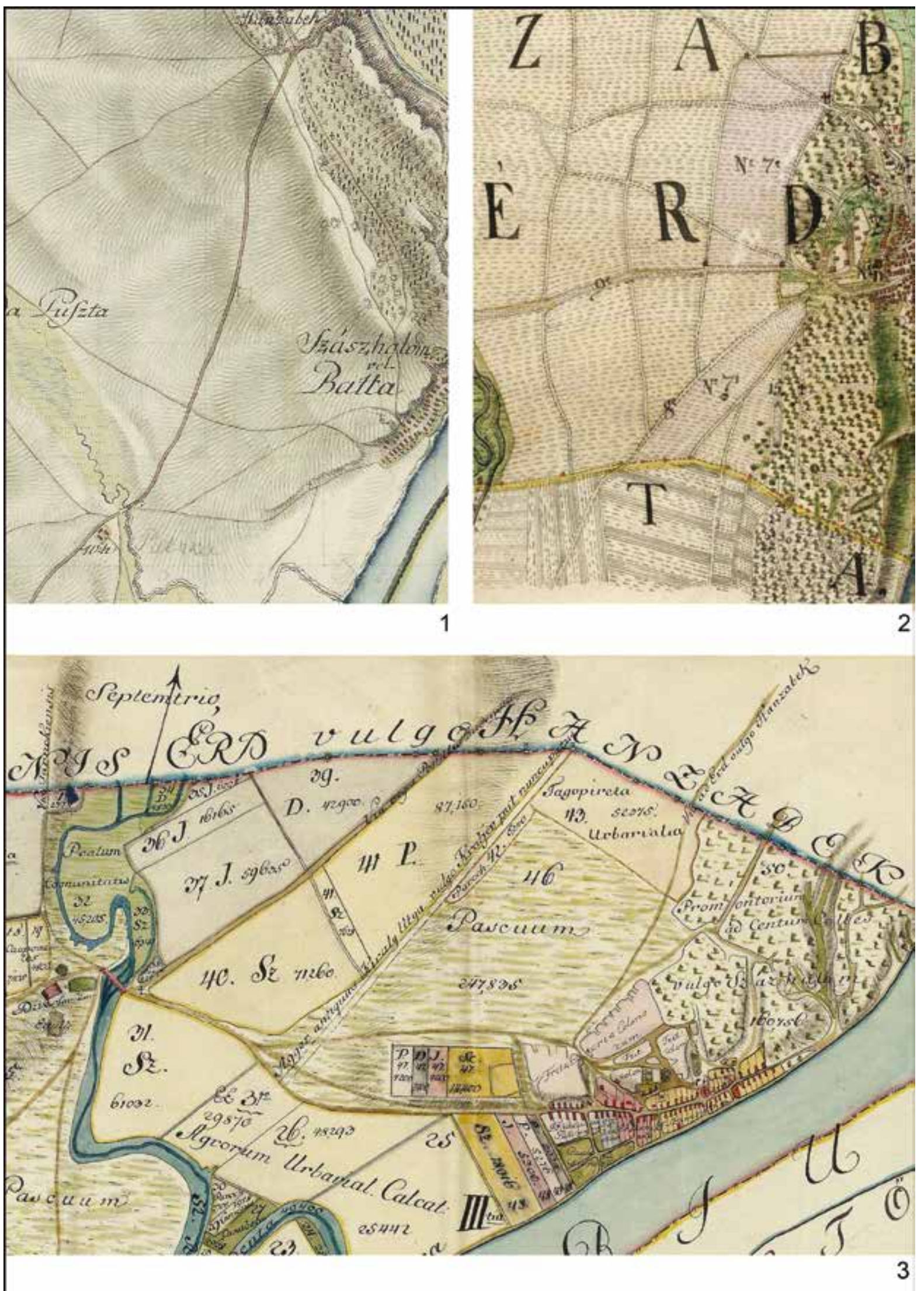

5. kép. 1: az első katonai felmérés részlete, 1783; 2: részlet egy Érdet ábrázoló falitérképről, 1783 (OSZK TF 4); 3: Benyovszky Imre Százhalombattát ábrázoló térképének részlete, 1795 (MNL OL S 113, No. 1)

Fig. 5. 1: detail from the first military survey, 1783; 2: detail from a wall map of Érd, 1783 (OSZK TF 4); 3: detail from Imre Benyovszky's map of Százhalombatta, 1795 (MNL OL S 113, No. 1) 
san ejtödôtt intabulatát illeti, ez az igasságnak vezérlése szerént megorvosoltassék.

Hogy tehát a' tisztelt Gróf Ur(nak), a' ki iránt $a^{\prime}$ $N$ (emes) V(árme)gye mindenkori szíves tiszteletét megbizonyítani akarja, ezen panaszai megorvosoltassa(nak), Tekéntetes Végh Ignátz Táblabiró, Kazay János Fő Notarius, ugy a' járásbeli tisztviselők és a' Földmérő Urak választság gyanánt kiküldet(nek), a' kik Fö Ispán Ur Ö Excellentiájá(nak) említett kegyes javallata szerént mind $a^{\prime}$ posta út, mind pedig $a^{\prime}$ vizállások(nak) letsapolása iránt véleményooket ide bemutatándják, a' panasznak harmadik pontjára pedig alább előkerűlendô intézetekkel fog ügyeltetni."23

A kiküldöttek ugyanebben az évben a következő jelentést tették: "Méltóságos Gróf Szapári János Úr Ő Excellentiája f(olyó) e(sztendő) 224. sz(ám) a(latt) bejegyzett kívánságainak megtekéntése végett kiküldetett Deputatio jelentette; hogy az Erdröl Ertsinek, 's Adonynak menő postaút lapáljai, és nagyobb ereszkedők miatt jóllehet esztendönként két izben is megigazittatni szokott, mint nem töltött út állandó tökéletességre nem hozathatik azért mivel $a^{\prime}$ Duna áradásnak hatalma és a' víz mosásoknak sokasága tsak hamar ismét elrontja a' régi Római útnak nyomdoki pedig $a^{\prime}$ magasabb helyeken mindenütt látszanak, de a' Lapokon már nyomai elvesztek, azt mindazonáltal lehet észrevenni, hogy ez keskeny ugyan, de magos, és egyenes tsapásban ment, és ezen út a' dombokon kevesebb költséggel igazittathatnék meg, de a' Duna kiöntéseitől szenvedö lapokon igen költséges töltések, és sokba kerülő hídak által készittetthetnék meg; sôt ha a' Római út választatnék, akor $a^{\prime}$ Battai nagy kö hid szükségtelen lenne, és helyébe máshol még nagyobb, és költségesebb hidat kellene építeni. A' mi pedig az Ertsi szöllök aljátol fogva egész az Ivántsai határig kiterjedő Lapban húzatni kivánt tsatornát illeti, e'ből az Ertsi jobbágyságnak mivel az az égyik vetöjé(nek) nagy részében ott a' vizáradással esztendönként károsodik, tetszetös haszna fordulna, különben pedig ezen tsatornának tsak egy öl szélességünek, és fél öl mélységünek kell lenni, és így az Ertsi jobbágyság által is hamar megkészittethetnék.

Minthogy ezen tárgynak első pontja iránt a'ról, hogy a' régi Római útnak helyrehozása, vagy a' mostani útnak feltöltése háritana é az adózó népre nagyobb tehert, még tökéletes jelentést azért nem lehetett késziteni, mivel a' folyamodó méltóság által kiszóllíttatni ajánlott Kormánybeli Földmérö sem jelent meg, de külömben ezen végre mind $a^{\prime}$ régi, mind a' mostani útnak ez esetben mennyire menö költségért kellene földméröi felszámitás által megtudni, azért a' megyebeli Földmérö Úr fog kiküldettetni, hogy az említett kormánybeli Földmérönek mikori kijövetele iránt is előre értekezvén, a' Méltóságos Urasággal az egész

23 FML Nemesi közgyúlések jegyzőkönyvei, 1813. február 23-25., Nr. 224, 58-59. lap. megyebeli Dunamelléki kérdésben forgó útat úgy a' régi Római útnak ugyan azon messzeségben terjedő tsapását mérték, és helyheztetés szerént felvegye, a' két rendbeli költségeket öszvejegyezze, és elkészitendö munkáját ide bemutassa. Továbbá az emlitett tsatornának ásása eránt jóvá hagyatván a' Deputátiónak véleménye járásbeli Fő Szolgabíró Úrnak meghagyatott, hogy ezen munkához az Ertsi jobbágyokat az Uraság által naponként fizetendő 24 krajczáros bér fejében kiparantsolni engedje, és addig is még ezen tsatorna elkészül, a' mondott községet a' Sárvizi munkátol felszabadítsa, ellenben pedig a Sárvizhez szükséges munkásoknak felosztásakor a'ra figyelmezzen, hogy az Ertsiből elmaradandó embereknek száma, az egész megye által potoltassék, melly a' miheztartás végett itten is megjegyeztetik." 24

1814-ben a megyei földmérő, Csapó Benjámin felmérte a két utat: „Chapó Földméró Úr a' 29dik számra jelentette, hogy az Érdrül Adonynak menö Posta utat, ugy a' régi Romai utat megtekéntvén tapasztalta, hogy ez az elsöbbnél nem tsak alkalmasabb volna, sött kevesebb költséggel helyre is állittáthatna, melly Kémenéserül készitett munkáját be is mutatja.

Meg fog kérettetni a' N(agy) M(éltóságu) K(irályi) H(elytartó) Tanáts, hogy a' Felsö Helyröl némelly ehez ertö Személyeket Kiküldeni méltóztasson, akik a' mi kiküldötjeinkel együtt, ezen javalott utat megvizsgálván, ha ez a' Felsö helyen is helyben fog hagyatni, minket ezen utnak elkészittésében, a'mellyre magunktol elégtelenek vagyunk elésegitteni méltoztasson." 25

Ennek a döntésnek megfelelően a közgyúlés a következő magyar nyelvú levélben terjesztette fel javaslatát a Római út lekövezésére:

„Felséges, Tsászári Királyi, és Ausztriai Örökös Fő Hertzeg Nádor Ispán Úr, Nagy Méltóságu Magyar Királyi Helytartó Tanács, Kegyelmes Urunk! Kegyes, és joakaró Uraink!

Nagy Méltóságu Gróf Szápáry János Úr Ő Excellenciájának a'beli kivánságára, hogy mivel $a^{\prime}$ Budáról, Ertsin keresztül menő Országútnak igazitása, $a^{\prime}$ Dunának áradásai miatt ${ }^{26}$ gyakran igen költségesé tétetik, az Érdi, Battai, és Ertsi határokban Adony felé látható régi Romai út megtekéntessen, Megyebeli Földmérőnket kiküldvén; ez e'beli végzésünknek következésében készitett munkáját mái napon elönkbe terjesztette; mellyet Tsászári Királyi Fö Hertzegségednek, és a' Nagy Méltóságu Királyi Helytartó Magyar Tanátsnak a'zal az alázatos kéréssel aláküldeni kivántunk, hogy először is e' tárgyban bizo-

24 FML Nemesi közgyúlések jegyzókönyvei, 1813. május 10-12., Nr. 585, 138-140. lap.

25 FML Nemesi közgyúlések jegyzókönyvei, 1814. május 9. és 11., Nr. 765, 189-190. lap; ZÁBORSZKY 1985, 209.

26 Tehát téves KovÁcs 1999, 61. és 101., 4. jegyzet azon állítása, hogy a közlekedés 1814-ben a napóleoni sáncok megépítése miatt került át újból a római útra. A hivatkozott NAGY 1972, 235-236. sem tartalmaz ilyen adatot. 


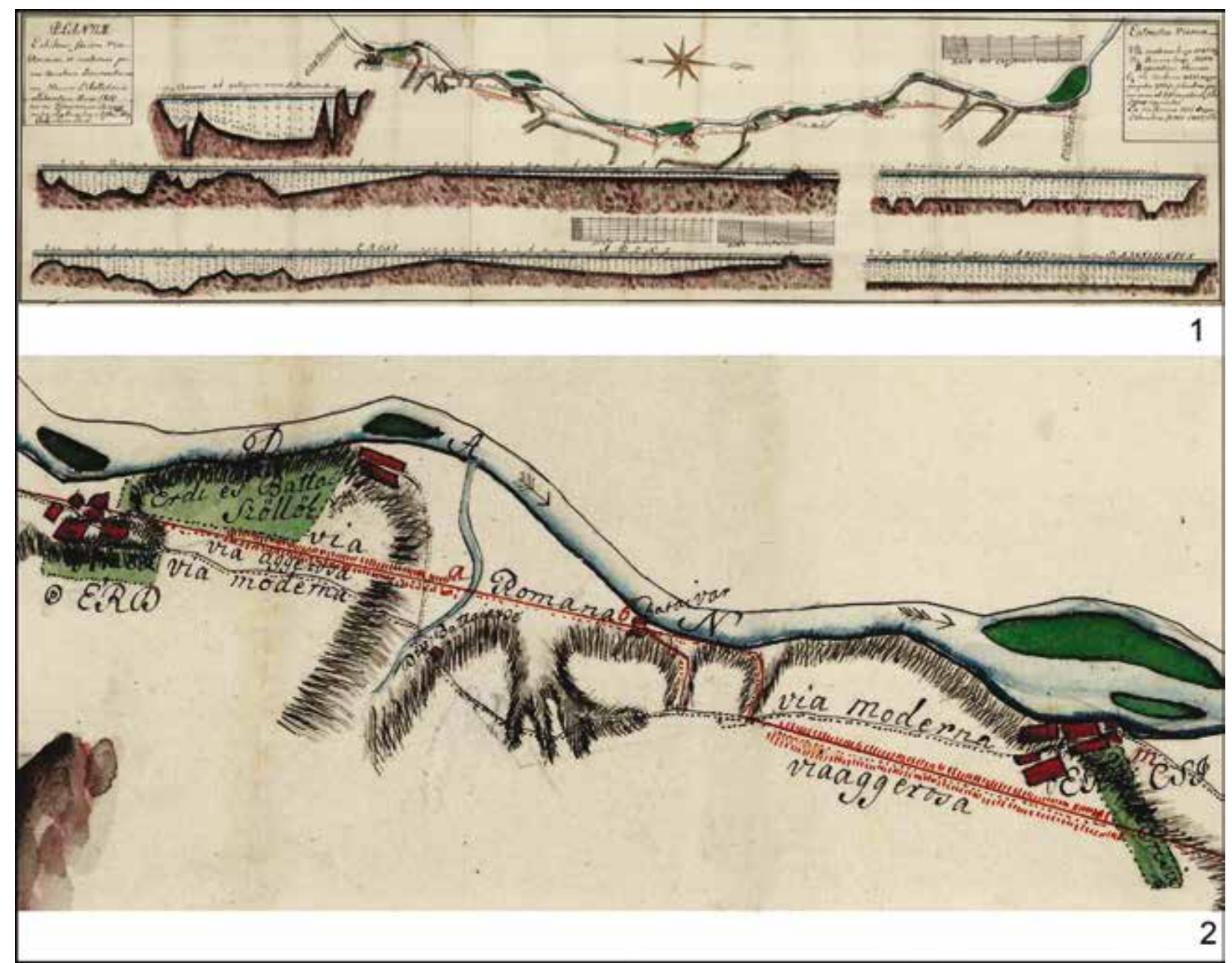

6. kép. 1-2: Csapó Benjámin felmérése a postaút és a Római út Fejér megyei szakaszáról, 1814 (MNL OL S 12 Div. XIII. No. 424) és a felmérés részlete

Fig. 6. 1-2: Benjámin Csapó's survey of the "Postal road" and the "Roman road" in Fejér County, 1814 (MNL OL S 12 Div. XIII. No. 424), and its detail

nyos kiküldötséget, a' ki ezen munkát, úgy azt is, hogy $a^{\prime}$ két út közül mellyikből háromlana több haszon $a^{\prime}$ közönségre nézve, az általunk is e' végre kiküldendő Tisztviselöinkenek egyetértésével bövebb vizsgálatra vegye, rendelni; azután pedig ha a' javallott Romai út hasznosabbnak, és alkalmatosabbnak találtatnék, minket e'nek helyreálitásában kegyesen elösegiteni méltóztasson. Töbnyire kegyelmébe, kegyességekbe, és jószivességeikbe ajánlottak, alázatos, és teljes tisztelettel maradunk alázatos, kész köteles szolgái.

Fejér Vármegyének Közönsége

Tsászári Királyi Fő Hertzegségednek

$a^{\prime}$ Nagy Méltóságu Királyi Helytartó

Magyar Tanátsnak.

Költ Székes Fejérváron 1814ik esztendei

Május hónapnak 3ik napján tartatott

Köz Gyülésünkből." 27
A levélhez csatolták Csapó Benjamin térképét (6. kép 1-2)28 és az ehhez tartozó latin nyelvú leírást is: "Ad instantiam Inclyti Domini Ercsi, in qua viae Romanae ex Oppido Érd versus Oppidum Adony et ultra se extendensis restaurationem exposcit, dignabatur Inclytus Co(mi)t(a)tus sub No 585 benigne determinasse ut in extensionem tam viae Romanae quam modernae Geometrice inquireretur, viae utriusque reparationi inhaerentes sumptus consignarentur; quae omnia sequenti modo deducta habentur.

Via moderna a limitibus Inc(lytus) Co(mi)t(a)tus Pestiensis, usque limites Inc(lytus) Co(mi)t(a)tus Tolnensis facit 33801 orgyas, via autem Romana 33324 orgyas in longitudine complectitur.

Ex Libellatione apparet viam Romanam, majori ex parte elevationi in loco sitam, nec adeo periculo exundationis, ac viam modernam expositam esse. 

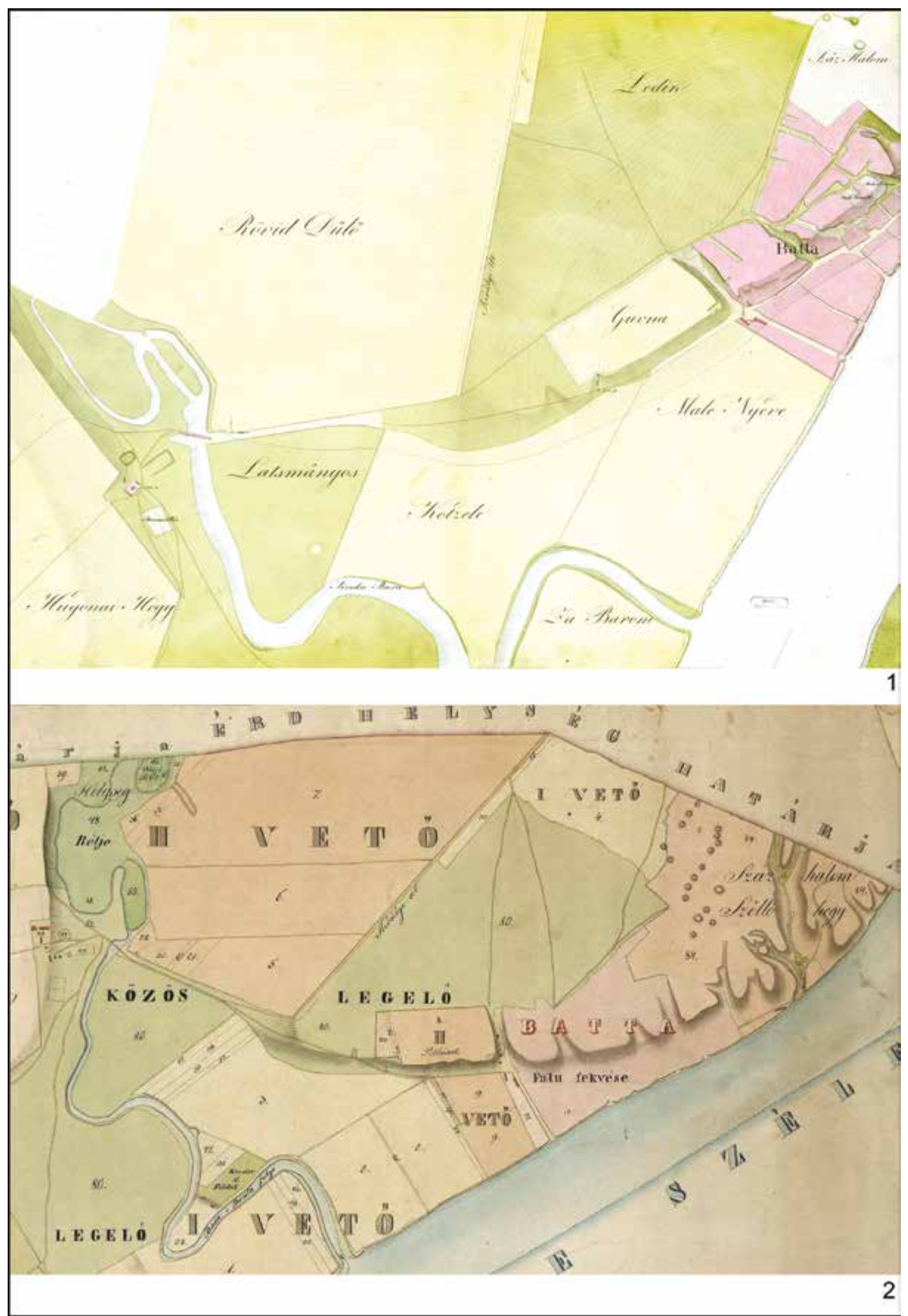

7 kép. 1: a Duna-mappáció részlete, 1826 (MNL OL S 80, No. 126/1038); 2: Rieder József Százhalombattát ábrázoló térképének részlete, 1837 (MNL OL S 156, No. 2)

Fig. 7. 1: detail from the Danube Mappation, 1826 (MNL OL S 80, No. 126/1038); 2: detail from József Rieder's map of Százhalombatta 1837 (MNL OL S 156, No. 2) 
Ad observandum viam Romanam, aliamque, in locis humilioribus ita elevandam esse, ut in eo itinerantes, etiam occasione maximae exundationis, non solum sine periculo, sed cum commoditare iter persciere possuit; quamobrem latitudo viae inferior ad 12 orgyas extensa sit oportet, ut sic etiamsi via ad debitam elevetur altitudinem, declivitas lateralis mollis sit.

Ex Calculo Libellationis evenit, quod pro reparatione 14847 orgyarum, quae ex via moderna reparari deberent $976091 / 2$ orgya Cubiae Terrae suit necessariae, unam Cubicam orgyam ab 8 grossis summendo 39043 floreni et 48 xferi. Ex via vero Romana 13307 orgyae renirent reparandae, ad quas 95830 orgya Cubiae Terrae 38233 floreni requiruntur ac praeterea duo pontes in Terreno Battaiensi et Ersiensi exstruendi, qui duo pontes ad 8000 fere florenos ascenderent. Ex predekretis apparet non totam viam, sed partem solum malam et humiliori in loco jacentem reparandam esse, nonnullo enim partes in loci ita elevatis decurrunt, ut nulla, aut peregi qua indigeant reparatione. Sign(atura) Alba Die 1a May 814

Beniaminus Chiapo

I(nclytus) Co(mi)t(a)tus Alb(ensis) Ord(inarius) et per Inc(lytus) Reg(num) Hung(ariae) Jur(atus) Geometra"29

29 Jankovich-Bésán Dénes fordításában: Ercsi tekintetes urának kérelmére, melyben az Érd városából Adony városába és azon túl vezető római út kijavítását kérte, 585. szám alatt a nemes vármegye kegyelmesen elhatározta, hogy úgy a római, mint a modern utat mérnök egészítse ki, mindkét út felújításának költségeit határozza meg, melyeket mind a következő módon kell levezetni.

A modern út nemes Pest vármegye határától nemes Tolna vármegye határáig 33801 ölet, a római pedig 33324 ölet tesz ki.

A szintezésből kitetszik, hogy a római út nagy része kiemelkedik, nincs annyira kitéve az elöntés veszélyének, mint a modern.

A római utat és a másikat a nedvesebb helyeken úgy kell megemelni, hogy azon az utazók a legnagyobb elöntés idején is nemcsak veszély nélkül, hanem kényelmesen átmehessenek, amiért az út alsó szélességét 12 ölnyire szükséges növelni, hogy így az út magasságát a szükséges módon megemelve, az oldalának lejtése megfelelő legyen.

A szintezés számításából az jön ki, hogy az 14847 ölet, melyet a modern útból javítani kell, 97609 és fél köböl földet igényel, köbölenként 8 garassal számolva 39043 forint és 48 krajcár. A római útból pedig 13307 öl javítandó, amihez 95830 köböl föld és 38230 forint szükséges, ezenkívül Batta és Ercsi területén két hidat kell készíteni, melyek [költsége] 8000 forintra rúghat. Az elmondottakból látható, hogy nem az egész út, hanem csak a rossz, illetve nedves helyeken fekvő szakaszok lennének kijavítva, így néhány szakasz vagy hely megemelt lenne, de, ahogy elmondtam, nem minden [szakasz] igényelne javítást. Kelt Székesfehérvár, 1814. május 1.

Csapó Benjamin

Nemes Fejér vármegyei rendes és a nemes Magyar Királyságra esküdt földméró

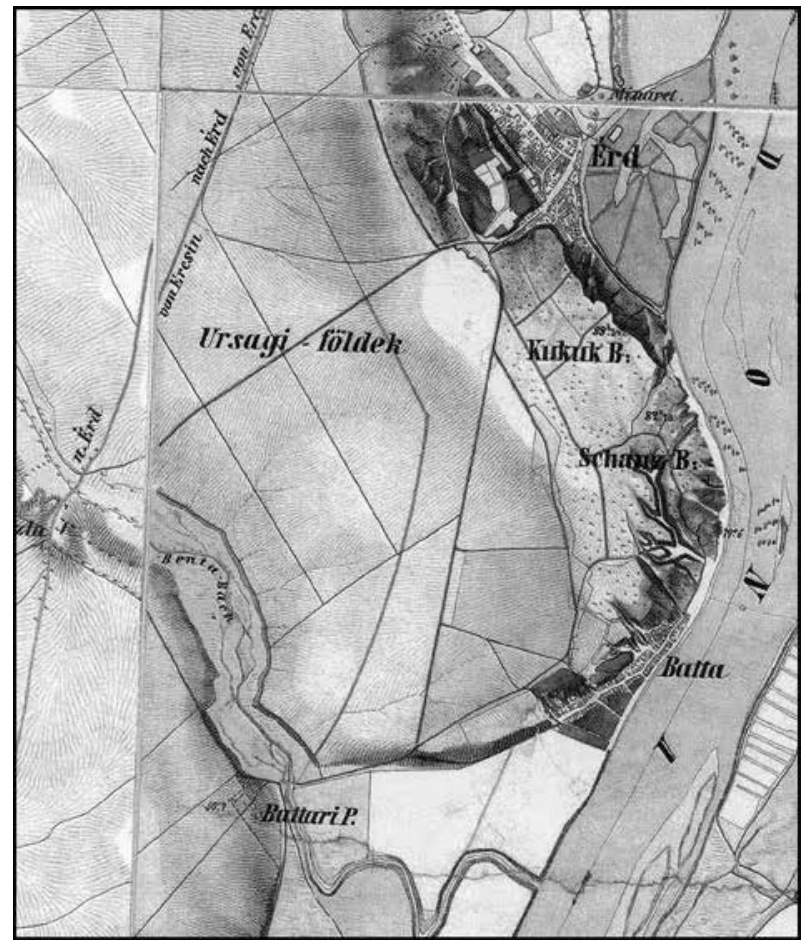

8 kép. A második katonai felmérés részlete, 1858

Fig. 8. Detail from the second military survey, 1858

A javaslatot ugyan a helytartótanácson belül továbbadták, ${ }^{30}$ de még ebben az évben kiküldték a kért földmérőt: „F(olyó) e(sztendő) Julius 19én 18847. szám alatt a' $N$ (agy) M(éltóságu) K(irályi) H(elytartó) Tanáts jelenti, hogy a' Budárol Ertsibe vezetö utnak megvizsgálására Eöri nevezetü Geometrát azzal az utasítással kiküldötte, hogy az a' Nemes Vármegye által rendelendő Deputatusoknak egygyütt való Munkálkodásával a' nevezett Útat, hogy azt miképpen lehet helyre állitani, megvizsgalja; melyrül is tudósitás kivántatik.

30 "Advolutam repraesentationem Co(mi)t(a)tus Albensis in negotio restaurationis viae ductus Buda per Ercsi decurrentis, isthuc substratam, Aedili huic Directioni eo subnexo hisce transponi, ut adnexam relationi huic Mappam spectantemq(ue) ad eandem geometricam elucubrationem examinet ac subin isthuc referat, num utraque sufficiens ad subversantem quaestionem medio Comissionis in facie loci discutiendam praebeat adminiculum nec nequibus item posteriori in casu ad miniculis opus adhuc foret."

Jankovich-Bésán Dénes fordításában: A Fejér vármegyéhez benyújtott előterjesztést a Budáról Ercsin át vezető út felújításáról ide az Építési Igazgatóságra átteszem azzal, hogy az idecsatolt térképet és mérnöki kimutatást vizsgálja meg és tegyen jelentést, hogy vajon mindkettő elegendő-e arra, hogy a Tanács közremúködésével a kérdést a helyszínen megtárgyaljuk, nyújtson segítséget, és a későbbiekben is legyen ugyanúgy segítségünkre. 
Az ezen dologban már kiküldött Deputationak $a^{\prime}$ Miheztartás, és az elvégeztekröl való Jelentés végett Kiadattatik." 31

1818-ra biztosan elkészült az út szóban forgó, az Érdi-fennsíkon Százhalombatta felé vezetó szakasza, mivel az ez évi hídösszeírásban a százhalombattai „Római” híd mellé a következő bejegyzést írták: „Ezen híd azelőtt az Ország útban volt, de mióta a Római út készül, már abban nintsen."32

Ugyanebben az évben már ezen a szakaszon jár a császári posta delizsánsza is: ${ }^{33}$ "M(egelőző) e(sztendő) November 25ki 3497. sz(ám) a(latt) $a^{\prime}$ Budárul Eszékre vezetô Pósta ut, mellyen a' Szorgalom Szekér rendszeresen szokott előlmozdíttatni jó, és haszontehetö állapotban tartani rendeltetik.

Te(kin)t(e)tes Zlinszky Ignácz Tábla Bíró Urnak a' már é tárgyban, jelessen pedig az ugy nevezett Római Ut e'ránt, melly a' kérdéses utnak egy részét teszi, való kiküldőttsége kővetkeztében ezen K(irályi) Parantsolat ki adatik, közöltetvén az illető Fő Szolga Bíró Urral is a' miheztartás végett. - Egyszersmind pedig a' $N($ agy) M(éltóságu) M(agyar) K(irályi) H(elytar)to Tanátsnak is béjelentetik, hogy azon ut munkában vagyon ugyan, de tökélletessen még helyre állittása nem eszközöltethetett." 34

„Nem külömben a' N(agy) M(éltóságu) M(agyar) K(irályi) H(elytar)to Tanáts f(olyó) e(sztendő) Majus 18rol 13840. sz(ám) a(latt) Kegyessen parantsolja, hogy azon Budárol Zemlinbe vezetö Utat, a' mellyen még most tsak próba tétel gyanánt $a^{\prime}$ Diligentialis Szekér ezen M(egy)én keresztül járt jól el készittessen, és továbbá is jó karban megtartasson, hogy netálan annak járhatatlan volta miatt $a^{\prime}$ Diligentialis szekérnek más felé kellessék útját venni.

Alázatosan válaszoltatik $a^{\prime}$ Tisztelt Tanátsnak, hogy ezen Megyében minden utak jó karban tartatnak, valamint az is, mellyen a' Diligence szekér jár, mostanában járható, ollyan azonban azon vidéknek helyheztetése, hogy a' Dunának nagyobb áradásaitol az utat oltalmazni nem lehet, ha tsak véghetetlen nagy töltés, mellyhez egy $M($ e)gye költségei, és ereje éppen elégtelen, fel sem állittatik, egyéb e'ránt azon esetben is, midőn a' vizáradás az egyenes Posta Utat járhatatlanná teszi, annyibol lehetséges $a^{\prime}$ járás, hogy Megyebeli Rácz Keresztúr, és Perkátai Helységek felé kerülvén, ottan mindenütt alkalmatos ut találtatik."35

31 FML Nemesi közgyúlések jegyzőkönyvei, 1814. augusztus 17-18., Nr. 1415, 342-343. lap.

32 GÁll 1970, 168.; Pesty 1864, 181., 1. jegyzet. A megadott hivatkozás (Acta Pol. 3-114, 1818.) az FML fondjegyzékének tételeivel nem azonosítható, így az iratot nem ismerem.

33 A postajáratokra nézve lásd HORVÁth 1981-1982, 185-187.

34 FML Nemesi közgyúlések jegyzőkönyvei, 1818. január 23., Nr. 13, 5-6. lap.

35 FML Nemesi közgyúlések jegyzőkönyvei, 1818. június 16-17., Nr. 1053, 344-345. lap. 1825-1826-ban azonban a Duna áradásai miatt az út több szakaszán is folytak út- és hídépítési munkálatok: „A N(agy) M(éltóságu) M(agyar) K(irályi) H(elytartó) Tanáts a f(olyó) e(sztendő) Januar 31ről 3103. sz(ám) a(latt) rendelni méltóztatik, hogy Tétény és Ertsi között a' Posta uton lévő Hidakra Karfák készittessenek, az ut két árok közé vétessen az jókarban tartasson, és ennek végben vitt eszközléséról Jelentés tétessen.

Ki adattatik Járásbeli Fő Szolga Biró Urnak, hogy Földmérő Urral egyetemben ezen utat megvizsgálván annak helyre állitásáról tanakodjanak, és arról Jelentéseket bé adják. - továbbá ugyan Járásbeli Fö Szolga Biró Urnak gondjává tétetik, hogy az illető Uradalmakat ezen utnak elkészittésére adandó segedelemért megkérjék, és e' tárgyban is a' Vár(me)gyét tudósittsák. - "36

„Szüts Lajos Fő Szolga Biró Ur jelentette a J(egyző) K(önyv) 1085. sz(ám) ra, hogy az ugy nevezett Romai utat az Érdi Erdöröl fogva az Ertsi Helységig Földmérő Urak megvizsgálván, azt tapasztalta légyen, hogy ezen utnak nagyobb része hegy oldalban lévén, azon helyeken árok közé a' Földnek homokos és könnyü léte végett nem szorittathatik, azon tájékon azonba, a'hol az ut térségen mégyen, annak árkolása megtörténhetik, az elöbb emlitett helyeken pedig ha az út 4. ölnyi szélességre kövétsel meghordattna, és a'hol a' viz az uton keresztül tsap azon helyek ki flastromoztathatnának, az út elegendöképpen megigazittathatna, jelenti továbbá, hogy a' Bentai töltésen lévö hidak közül, minthogy ezen Töltésnek szomszédságában lévö halas tó leeresztettvén, 3 Hid megszüntethetik, és így tsak kettönek ujjitása, vagy is inkább ujjonnan leendö felépittése szükséges, melly Hidaknak felépittésére megkivántató faragott követ téglat, Követ és meszet az Erdi Uradalom megigérte légyen.

Meghagyatik Jelentő Fő Szolga Biró Urnak, hogy az érdeklett utnak helyre állittására ügyelvén, $a^{\prime}$ Hidaknak felépittése eránt a' Kömives mesterrel megalkudjon, és ha azok elkészülnek a' költségek jegyzéket bémutassa, - egyszersmind a' N(agy) M(éltóságu) M(agyar) K(irályi) H(elytartó) Tanáts f(olyó) e(sztendô) Januar. 31én 3103. sz(ám) a(latt) költ kegyes Parantsolatja következésében e' tárgyról tudósitatni fog, - a' mi pedig az Érdi Uradalom által ajánlott segitséget illeti az az egyben gyült Rendek által köszönettel elfogadtatott. - "'37

„Szüts Lajos Fő Sz. Bíró Ur jelentette a' J(egyző) K(önyv) 316. sz(ám)ra, hogy a' Bentai töltésen épittendő két kő hidak tsinálására nézve a' Kömives Mesterrel 425. f(orin)tokba megalkudott légyen,

36 FML Nemesi közgyúlések jegyzőkönyvei, 1825. május 18-19., Nr. 725, 252-253. lap.

37 FML Nemesi közgyúlések jegyzőkönyvei, 1825. december 12-13., Nr. 1985, 742-743. lap; ZÁBORSZKY 1985, 209., 138-139. jegyzet, tévesen Nr. 1895-ként. 
mellyröl mivel a' Hidak már tökéletessen elkészültek, $a^{\prime}$ Kömivesnek alkú levelét $a^{\prime}$./. alatt, ugy az Érdi Átsmesternek $a^{\prime}$ boltozatokhoz szükséges 36. szál deszkáért 17. f(orin)t 36. kr(ajczár)okról szolló Contóját $a^{\prime}$ ://: alatt, nem külömben Geiszt János Köfaragó Mesternek 35. f(orin)tokról szolló Jegyzéket $a^{\prime}$.../I/... alatt ki fizetés végett bé mutatta. - jelentette továbbá szóval, hogy a' Tétény és Ertsi között lévó Posta utnak, vagyis az ugynevezett Romai utnak tsináltatása már munkában vagyon, de még tökéletessen el nem készitethetett. -

$A^{\prime}$ bé mutatott három rendbeli Jegyzékek Fó Adóvevő Urnak kifizetés végett kiadattatnak. - Az érintett Hidak tsinálásához megkivántatott, és megmaradt deszkáknak gondviselése addig, még azokat más valamellyes Hidakra alkalmaztathatja, Járásbeli Fő Szolga Bíró Urnak kötelességül tétetik: Egyszersmind az ugynevezett Romai utnak tökéletessen leendó elkészitése továbbá is gondjává tétetik. Egyébberánt a' N(agy) M(éltóságu) M(agyar) K(irályi) H(elytartó) Tanátsnak f(olyó) e(sztendô) Januar 10 ról 895. sz(ám) a(latt) költ kegyes Parantsolatjára válaszképpen megirattatik, hogy a' Bentai töltésen a' megkivántatott két hidak már el-készülvén a' Tétény és Ertsi közt lévö Posta vagy is az ugy nevezett Romai utnak készittése pedig már munkában vagyon. -"38

A Duna-mappáció 1826-ban készült szelvénye „Királyi Út” felirattal a környező utaktól eltérően nem egyetlen vonallal, hanem széles sávként jelöli az utat, amely a battai bekötőútig tart (7. kép 1). A korábbi postautat már nem tüntette fel..$^{39}$

Rieder József 1837. évi, Százhalombattát ábrázoló térképén „Királyi ut” felirattal jelöli a római utat (7. kép 2). ${ }^{40}$ A többi úttal ellentétben széles sárga sávként jelöli, szintén a faluba vezetó bekötőútig. ${ }^{41}$ A korábbi postautat már ő sem jelölte. Ez az első térkép, ahol a mai 6 . sz. fóút nyomvonalával megegyező út is megjelenik (ez a rész az itt közölt kivágaton nem szerepel). Ezt ugyanazzal a széles sárga sávval jelöli, mint a Római utat.

1847-ben említette először tudományos értekezés a Római utat. Érdy (Luczenbacher) János a bronzkori halomsíros temető kapcsán csak enynyit írt: „A' mint az érdi mély útból kiértünk, eloottünk állottak a' Tárnokvöloy' rétjei, mellyeken római út vonúl keresztül."

38 FML Nemesi közgyúlések jegyzőkönyvei, 1826. június 13-14. Nr. 794, 237. lap; ZÁBORSZKY 1985, 209., 138-139. jegyzet, tévesen Nr. 795-ként.

39 MNL OL S 80, No. 126:1038; FML T 288.

40 MNL OL S 156, No. 2; KovÁcs 1999, 61, T. XCII; KovÁcs 2000, 10, Fig. 5. 1830-ra datálva.

41 Ennek ellenére is hitelt adhatunk a közgyúlési jegyzőkönyveknek, miszerint az út Százhalombattán is megépült, mivel Kovács Péter megfigyelte az út egy szakaszát. Kovács 1999, 101., 2. jegyzet.

42 LUCZENBACHER 1847, 285, V. tábla.
Ugyanebben az évben Fényes Elek Érdnél a következőt írta: „Láthatni itt még ... a régi romai országut maradványait." 43

Hasonlóan lakonikus Johann Gabriel Seidl 1853. évi megjegyzése: „....sieht man grossartige Reste einer Römerstrasse..."44

Az 1858-ban készült második katonai felmérés a maival megegyező vonalú útként ábrázolja a Római utat (8. kép). ${ }^{45}$ A korábbi postaút déli szakaszát feltünteti, de északi szakaszát ekkorra felhagyták.

Az 1864-ben összegyújtött, Pesty Frigyes nevével fémjelzett helységnévtár adatai szerint a helyiek római kori útként tartották számon az Ófaluban ma is Római út néven ismert utcát ${ }^{46}$ és az itt szóban forgó, százhalombattai határban húzódó utat is. ${ }^{47}$ De a két utat összekötő mai Mély utcát azonban már akkor is a bevágódásról nevezték el. ${ }^{48}$

Ugyanebben az évben Rómer Flóris ezt írja a Római útról: „Érdnél a Tétényi csárdán alúl 600? lépésnyire a régi posvány szélén megy el - és betér a római ut, melynek köveit, és kövezetét mindenhol tisztán látni - Érden túl a hegyen ismét a hídig tisztán látható."49

Még szúkszavúbb Kereskényi Gyula 1874-ben: „az országut ... mai napig is áll Százhalomnál." "Érd fölött emelkedő hegyen ... halad az Aquincumtól erre vezető, s most is épségben fennálló ezredéves római ut."

1896-ban Károly János így írta le a Római utat: „... a Csillag-csárdán alul az Érdre vezetó út kiágazik; mert ettôl a ponttól az érdi út mindenütt a ma is látható, de sohasem javitott római uton halad, halad egészen be Érdre a kápolna elött. ... A római út Érd öreg

43 FÉNYES 1847, 42; FÉNYES 1851, 306

44 SEIDL 1853, 158

45 Colonne XXXII, Sectio 52.

46 PESTY 1864, 205: „Érd községnek elóbbi topografikus fekvése változáson ment által az 1838. évi dunai nagy árvíz miatt, mert az ekkor romba dỏlt házak tulajdonosai, az elóbbi régi római ut mellól a magasabban fekvő úgynevezett Ráma- és Sumár dülők térségére épitkeztek a Buda-fehérvári országútig; ..."

47 PESTY 1864, 207: "Megyunkai-dűlő, fekszik délről a battai határ mellett keletnek, a hasonnevü szölő-dülő szomszédságában, nyugotnak a római útig dül." "Zanovet-dülo", délról a battai határ mellett, nyugotról a Bentai rétre dủl, s keletröl a Megyunkai-dülő alatt a római út mentében fekszik." PESTY 1864, 208.: „Bile guste dủlő. ... Állítják, hogy e helyen, Fel-Diósd község felé feküdt a hajdan nevezetes Potentiana római vár és város, mely mellett a lejjebb eső érdi határon is nyomaiban még látható régi római út húzódott, s a diósdi szőloókön által a budaörsi sorompó irányában csatlakozott Budával, az akkori Aquincummal."

48 PESTY 1864, 206: „Gyorma illír szó s magyarul: két hegy között lévö feljárásra használt mélyedést jelent, Mivel ezen szürüs kertekbe ily mélyedésen jutni fel, ezen mélyedéstól nyerte Gyorma nevét."

49 RÓMer jkv. XIII, 153; Rómer 1878, 127, Fig. 50; PAUlovics 1957, 13; MRT 7, 102, 9/25. lelöhely.

50 KERESKÉNYI 1874, 13, 25. 

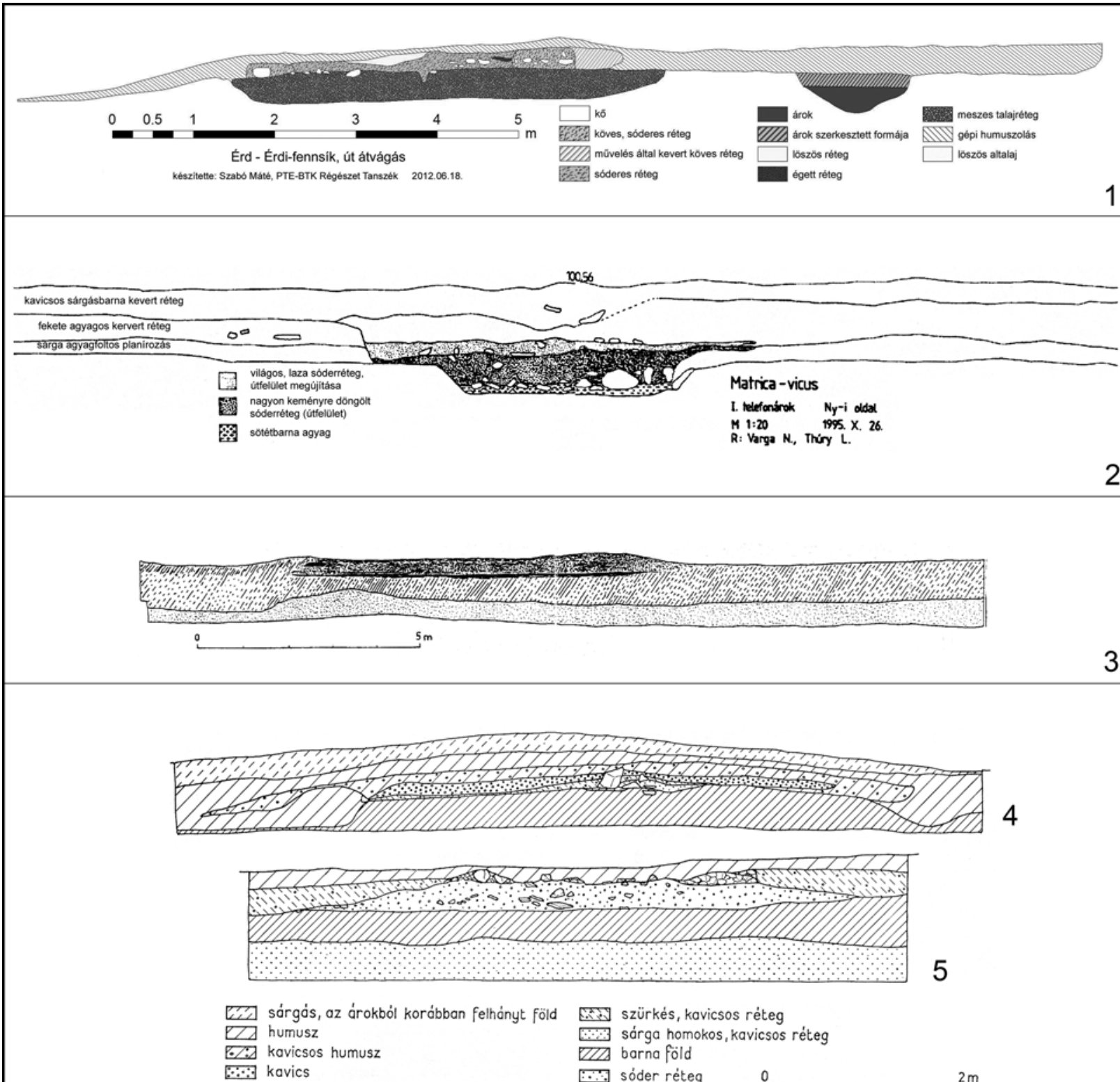

$\therefore \rightarrow$ kavics

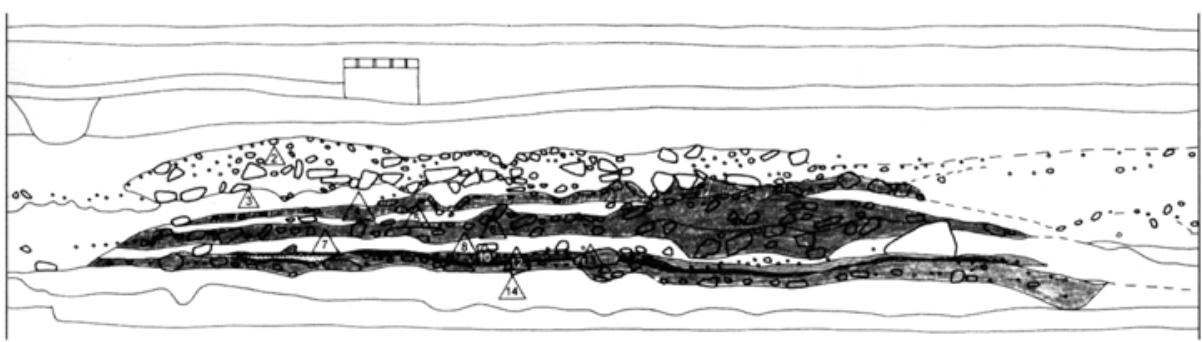

9. kép. Római kori útmetszetek Magyarország területéről. 1: Érd (SzABÓ 2014, 90, 7. kép nyomán); 2: Százhalombatta (KovÁcS 1999, T. LXXIX. nyomán); 3: Paks (VISY 2000, 137. ábra nyomán); 4: Nyergesújfalu (MRT 5, 271, 38. kép nyomán); 5: Tokod (MRT 5, 271, 38. kép nyomán); 6: Óbuda-Testvérhegy (LÁNG 2005, 663, Fig. 4. nyomán)

Fig. 9. Sections of Roman age roads in Hungary. 1: Érd (after SzABó 2014, 90, Fig. 7); 2: Százhalombatta (after Kovács 1999, T. LXXIX.); 3: Paks (after VIsY 2000, Fig. 137); 4: Nyergesújfalu (after MRT 5, 271, Abb. 38); 5: Tokod (after MRT 5, 271, Abb. 38); 6: Óbuda-Testvérhegy (after LÁNG 2005, 663, Fig. 4) 
utczáján felvezet abba a mély utba, mely a battai hunhalmok felé irányul, s megy a Tárnokvölgybe mindenütt a római alapépitkezésen haladva a mai út is, mely a Tárnok vizén keresztül vezető hármas ivü, rómainak mondott hídon átmenve, azon a dülön, mely Lits Gyula és Wimppfen Siegfrid gróf battai birtokaik között fekszik s »római út-dülönek « neveztetik, egyenesen Krizsán Dolina nevü majornál szakad be az ercsii országutba." ${ }^{51}$

A lelőhelyről a legkorábbi légi fotó 1940-ben készült, ezt 1978-ban publikálta Visy Zsolt. ${ }^{52}$ A légi fotókon a szántóföldön tisztán látható az egykori postaút nyomvonala. A Római út vonalán már a mai állapotnak megfelelően egy földút halad, de északi végével kapcsolatban, ahol a mai Mély úttal találkozik az út, Visy Zsolt a következőt állapította meg: „....korábban nem tett akkora kanyart a fennsík északi szélén, mint most, hanem csupán egy enyhe nyugati ivet leirva érte el észak felé haladva a mélyút kezdetét."53

1979-ben a Százhalombatta területén jelentkező kavicsos sávot Maróti Éva átvágta, és megállapította, hogy az út maradványait ezen a helyen már teljesen szétszántották. ${ }^{54}$ Ugyanekkor Torma István úgy vélte, hogy az érdi Mély út kövezete újkori. ${ }^{55}$

1994-1995-ben Kovács Péter azon a véleményen volt, hogy az út kövezete római kori, az újkori út építésére vonatkozó adatok pedig az egykori postaútra vonatkoznak. ${ }^{56}$

2000-ben Mráv Zsolt a Mély út felújítását megelőzően végzett feltárást. Megállapította, hogy a kőburkolat és a sóderes útalapozás is újkori. ${ }^{57}$

Forrásaink és a szakirodalom alapján tehát az út történetét a következőkben vázolhatjuk fel. A római kori út a középkorban is használatban volt. Ez azonban legkésóbb a 18. század első felére olyan rossz állapotba kerülhetett, hogy egy új útvonalat kezdtek el használni helyette. Ez utóbbit 18. századi forrásaink postaútnak, a római kori út maradványát Királyi útnak nevezik.

1814-ben a rossz állapotú postaút helyett Fejér megye közgyúlése a Római út nyomvonalán javasolja megépíteni az új utat. A tervezet természetesen nem mindenhol fedi pontosan az erede-

\footnotetext{
51 KÁROLY 1896, 102-103.

52 VISY 1978, 238., 3. kép; MRT 7, 59. tábla 1-2; VISY 2000, 61., 404. jegyzet, 84-85. ábra.

53 VISY 2000, 61., 84. ábra.

54 MRT 7, 240, 27/10. lelőhely.

55 MRT 7, 103, 9/25. lelóhely.

56 KovÁcs 2007, 219., 39. és 41. jegyzet. A 2007-ben megjelent írás 1994-1995-ben készült (KovÁCs 2007, 242), így a későbbi adatok nem kerültek bele.

57 MrÁv 2000.
}

ti római kori út vonalát, ${ }^{58}$ sőt néhány helyen több opciót is tartalmaz. Az új út 1818-ra elkészült Érdtől a Százhalombattára vezető bekötóútig.

A régi utat forrásaink 1814 előtt következetesen Királyi útként említik, azaz a helyi hagyomány nem a római korhoz, hanem a középkorhoz kötötte keletkezését. Az 1814. évi tervezetben szerepel először a Római út megnevezés, és ekkortól az érdi szakaszt következetesen ezen a néven említik.

Mivel a Római út több szakasza is a Duna árterületére esett, az utat minden árvíz után javítani kellett. Ezért legkésőbb 1837-re megépült a mai 6. számú főút, a Római út nem volt többé az országos úthálózat része, karbantartásával is felhagytak.

Tíz évvel később, 1847-ben járt először régész a lelőhelyen, az út kövezetéről pedig csak huszonhét évvel később, 1864-ben tett először említést Rómer Flóris. Ezeket a beszámolókat erősen befolyásolhatta a helyiek véleménye, amely az út elnevezéséból adódóan a kövezetet is római korinak tekinthette.

\section{Római út - római utak}

Az útról az egyetlen metszetrajzot Szabó Máté közölte (9. kép 1). ${ }^{59} \mathrm{Az}$ általa feltárt rétegek alulról kezdve: az altalajba mélyedő meszes, 5,3 m széles, $35 \mathrm{~cm}$ vastag alapozási réteg, közepén 10 cm mély, V keresztmetszetú mélyedéssel; ennek szélétól beljebb (a nyugati oldalon $20 \mathrm{~cm}-\mathrm{rel}$, a keletin $1 \mathrm{~m}$-rel) szabálytalanul rakott kövekból és sóderből álló útszegély, a két útszegély köze sóderrel volt kitöltve. A réteg vastagsága mindöszsze $20-25 \mathrm{~cm}$ volt. A sóderrétegen löszös sáv és modern égésréteg jelentkezett. Az út azonosítható szélessége $4 \mathrm{~m}$ volt, felszíne nyugat felé lejtett, kelet felől 1,4 m széles és az altalajba $30 \mathrm{~cm}$-re mélyedó árok kísérte. A köves réteg felszínéról és az égett rétegből modern fémhulladék került elő, az út keleti szélén feltárt köves szegélyből korhatározásra nem alkalmas kovácsoltvas szög és két bronztöredék került elő. Az út árkában római kori caligaszeget találtak. Az útmetszetben megújítás nyomát nem lehetett megfigyelni.

A Magyarország területén feltárt római kori utak szerkezete ettól eltér. Az utak vagy a humuszra - mint Százhalombattán (9. kép 2), ${ }^{60}$

58 Ezeket az eltéréseket Visy Zsolt is említi (VISY 2000, 64, 69), de ő a földmérő tévedésének tekinti e részleteket, nem pedig egy új út tervének.

59 SzAво́ 2014, 88-91., 7. kép.

60 Mócsy 1955, 60; KovÁcs 1999, 90, T. LXXIX. 


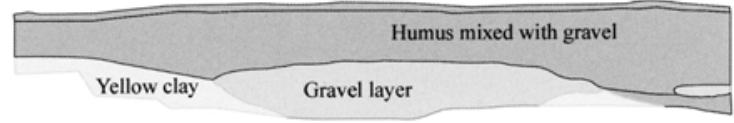

$\begin{array}{llllllll}0 & 1 & 2 & 3 & 4 & 4 & 1 & 5\end{array}$
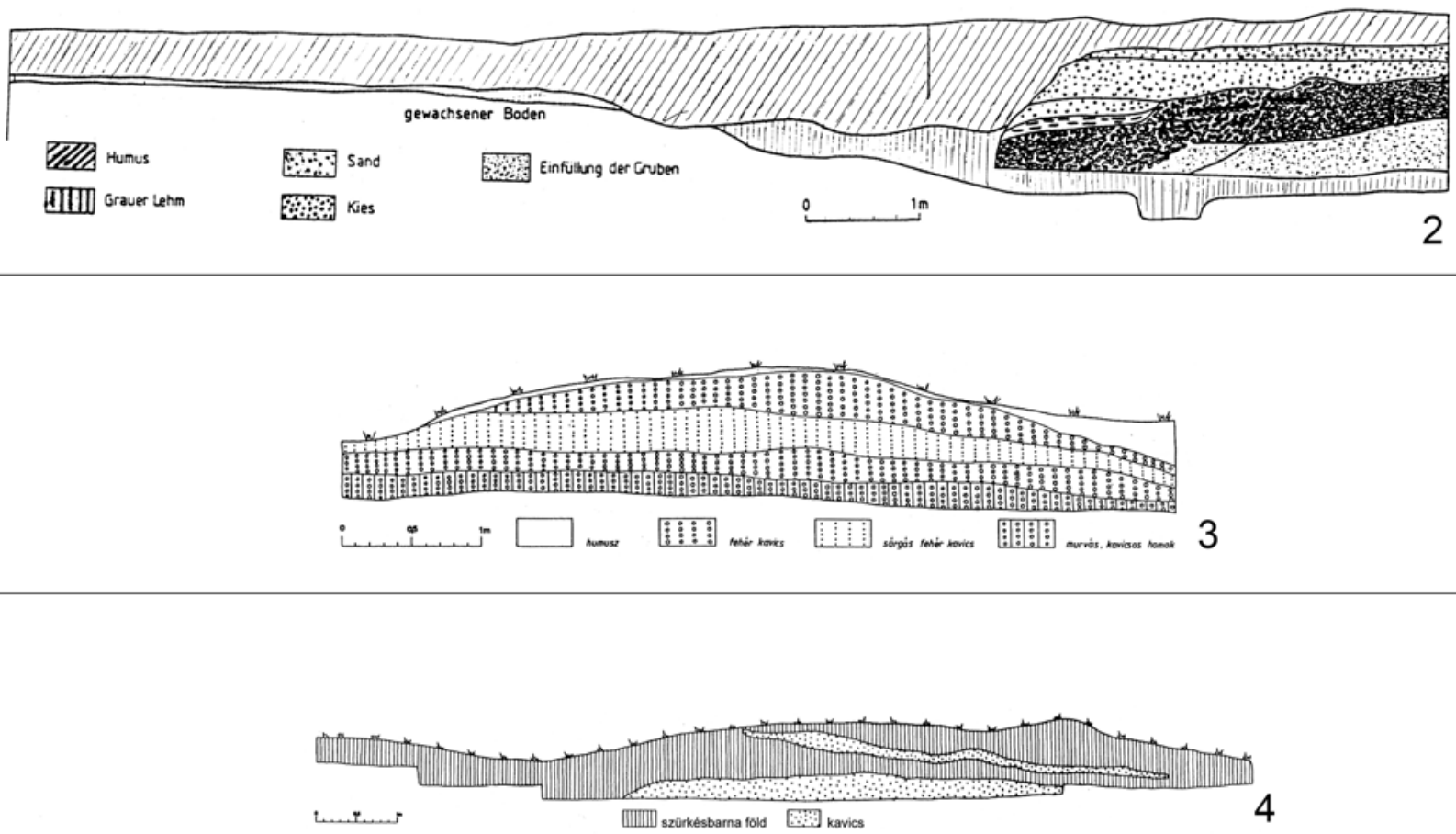

s.o.t

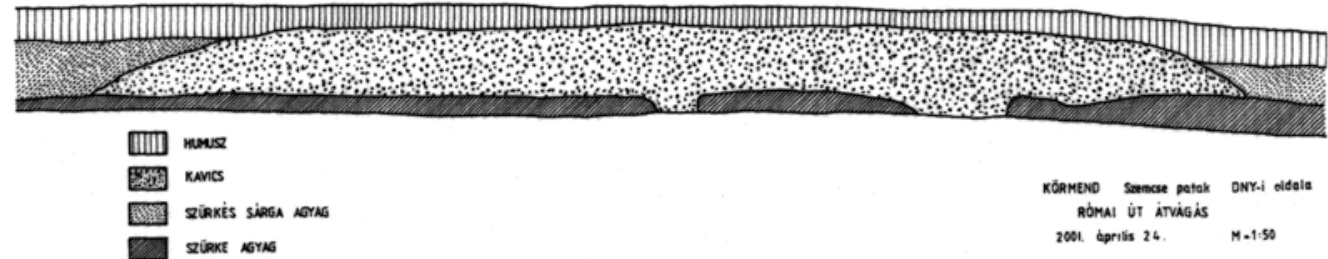

grenes nexpe

2001. berriss 26

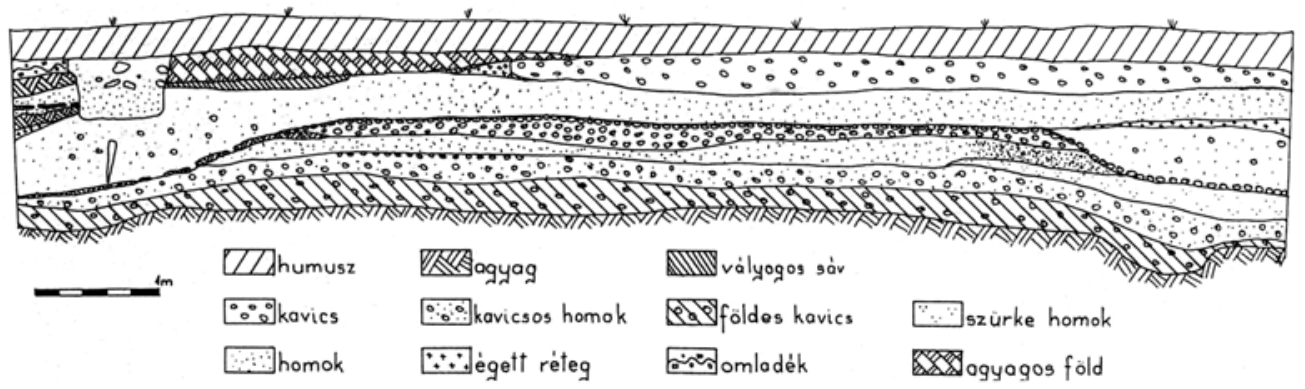


10. kép. Római kori útmetszetek Magyarország területéről. 1: Pankasz (REDó 2005, 106, Fig. 3. nyomán); 2: Sárvár (GABLER 1991, 41, Abb. 4. nyomán); 3-4: Kemenesszentpéter (PALÁGYI 1992, 6-7. ábra nyomán); 5: Körmend (VÁMOs 2000-2001, 215, 8. ábra nyomán); 6: Mursella (SZŐNYI 1999, 95, 5. kép nyomán)

Fig. 10. Sections of Roman age roads in Hungary. 1: Pankasz (after Redő 2005, 106, Fig. 3); 2: Sárvár (after GABLER 1991, 41, Abb. 4); 3-4: Kemenesszentpéter (after PALÁGYI 1992, Fig. 6-7); 5: Körmend (after VÁMOS 2000-2001, 215, Fig. 8); 6: Mursella (after SZŐNYI 1999, 95, Fig. 5)

Pakson (9. kép 3), ${ }^{61}$ Nyergesújfaluban (9. kép 4), ${ }^{62}$ Aquincumban az északkeleti táborsaroknál (11. kép 1) ${ }^{63}$ és a tábor déli frontján (11. kép 2), ${ }^{64}$ Óbuda-Testvérhegyen (9. kép 6), ${ }^{65}$ Tokodon (9. kép $5)^{66}$ és Nádasdon ${ }^{67}$-, vagy az altalajra épültek Zalalövőn (12. kép 1-4), ${ }^{68}$ Pankaszon (10. kép 1), ${ }^{69}$ Sárváron (10. kép 2) ${ }^{70}$ és Kemenesszentpéteren (10. kép 3-4 $)^{71}$-, de az érdi úttal ellentétben mindig a réteg felszínére épültek, sosem mélyülnek bele.

Számos útnak nincs külön alapozási rétege, hanem az egész út döngölt kavicsrétegből áll, mint Százhalombattán, ${ }^{72}$ Tokodon (9. kép 5), ${ }^{73}$ Zalalövőn (12. kép 1-6), ${ }^{74}$ Pankaszon (10. kép 1), ${ }^{75}$ Sárváron (10. kép 2), ${ }^{76}$ Kemenesszentpéteren (10. kép 3-4), ${ }^{77}$ Szombathelyen (11. kép 4-5), ${ }^{78}$ Nádasdon ${ }^{79}$ és Körmenden (10. kép 5). ${ }^{80}$

Ha az útnak alapozást készítettek, az ritkább esetben homokból - így Pakson (3. kép 3) ${ }^{81}$ és Mursellában (3. kép 12) ${ }^{82}$-, gyakrabban - így Százhalombattán (9. kép 2), ${ }^{83}$ Nyergesújfaluban

61 VISY 2000, 87., 137. ábra.

62 MRT 5, 270-271, 15/16. lelóhely, 38. kép felül.

63 NÉMETH 1976, 63., 12. ábra.

64 KÉRDÓ 1976, 71., 16. ábra.

65 LÁNG 2005, 659-660, 663, Fig. 4.

66 MRT 5, 331, 22/15. lelőhely, 271., 38. kép alul; KeLEMEN 1992, 24.

67 CSERMÉNYI-TÓTH 1979-1980, 183.

68 RFiZ 1975, 217-218, Abb. 8-10; RFiZ 1978-1979, 286, Abb. 20; RFiZ 1982-1983, 416, Abb. 13.

69 ReDŐ 2005, 106, Fig. 3.

70 GABLER 1991, 40-41, Abb. 4.

71 PalÁgyi 1992, 28, 33-34., 6-7. ábra.

72 Mócsy 1955, 60.

73 MRT 5, 331, 22/15. lelőhely, 271., 38. kép alul; KelEMEN 1992, 24.

74 RFiZ 1975, 217-218, Abb. 8-10; RFiZ 1976, 383, 384, Abb. 60; RFiZ 1977, 367, Abb. 13. (szövegesen nem említi); RFiZ 1977, 371, Abb. 21; RFiZ 1978-1979, 286, Abb. 20; RFiZ 1982-1983, 416, Abb. 13

75 REDÓ 2005, 106, Fig. 3.

76 GABLER 1991, 40-41, Abb. 4.

77 PALÁGYi 1992, 28, 33-34., 6-7. ábra.

78 Buócz 1971-1972, 201; Kiss-SoszTARIcs 1996-1997, 111, Abb. 4. (szövegesen nem említi).

79 CSERMÉNYI-Tóth 1979-1980, 183.

80 VÁMOS 2000-2001, 215., 8. ábra (szövegesen nem említi).

81 VISY 2000, 87., 137. ábra.

82 SZŐNYI 1999, 95., 5. kép.

83 KovÁcs 1999, 90, T. LXXIX.
(9. kép 4), ${ }^{84}$ Aquincumban az északkeleti táborsaroknál (11. kép 1), ${ }^{85}$ a tábor déli frontjánál (11. kép $2)^{86}$ és a tábor délkeleti negyedében (11. kép 3), ${ }^{87}$ valamint Óbuda-Testvérhegyen (9. kép 6) ${ }^{88}$ - nagyobb méretú kövekból készült, ",meszes talajréteget" eddig csak az érdi út alapozásánál regisztráltak.

Nincs párhuzama a kavicsréteget mindkét oldalról kísérő köves szegélynek sem. Szegélyköveket bazaltburkolatú utaknál ismerünk, de ezek csak a római kori településeken belül - pl. Szombathelyen (11. kép 5) ${ }^{89}$ és Zalalövőn (12. kép $3)^{90}$ - találhatók meg. Hasonló metszetet mutat a tokodi útrészlet (9. kép 5), itt azonban az alapozás két szélén megjelenó kövek esetében az eredeti kőburkolat maradványairól van szó. ${ }^{91} \mathrm{Ez}$ azonban szintén egy településen belül vezetó útszakasz volt, az érdi útnál - mivel lakott területen kívül vezetett - a római korban kőburkolatú járófelülettel nem számolhatunk.

Újkori utakról csak sematikus, tervekhez készült metszetek állnak rendelkezésünkre. Ezek között is csak elvétve találunk olyan ábrázolást, amely talán a felszín alá mélyülő alapozást mutat (13. kép 1-3).92 Itt is előfordulnak szegélykövek, ezek azonban az alapozás alá nyúlnak. Az Érden feltárt útmetszetből teljesen hiányzik az a kő alapozási réteg, amelyet az újkori metszetek feltüntetnek (13. kép 4-7). ${ }^{93}$ A korszakban azonban egységes útépítési eljárás nem létezett. "Azért minden Vármegyének és az Ország Igazgatóknak legfóbb gondolatjokat arra kellene fordítani, hogy az útak mindenüttegy bizonyos Theoriára és Praksisra épült Systhema szerint épitessenek, nem pedig az útaknak directiója egyedül egy Földmérótőll, a' ki

84 MRT 5, 270-271, 15/16. lelóhely, 38. kép felül.

85 NÉMETH 1976, 63., 12. ábra.

86 KÉRDŐ 1976, 71., 16. ábra.

87 KÉRDÖ 1997, 269., 3. kép.

88 LÁNG 2005, 659-660, 663, Fig. 4.

89 Kiss-Sosztarics 1996-1997, 111, Abb. 4. (szövegesen nem említi).

90 RFiZ 1982-1983, Abb. 13.

91 MRT 5, 331, 22/15. lelóhely, 271., 38. kép alul; KeLEMEN 1992, 24.

92 MNL OL S 11, No. 1415:2, Quer Profil 19-20; S 105, No. 18; PML XV. 6. (PMT) 5/8-9.

93 MNL OL $S 12$ Div. XIII, No. 0111/2; MNL OL S 101, No. 24, Mittel Querprofil ad Nr. 2; MNL OL S 105, No. 17-19. 


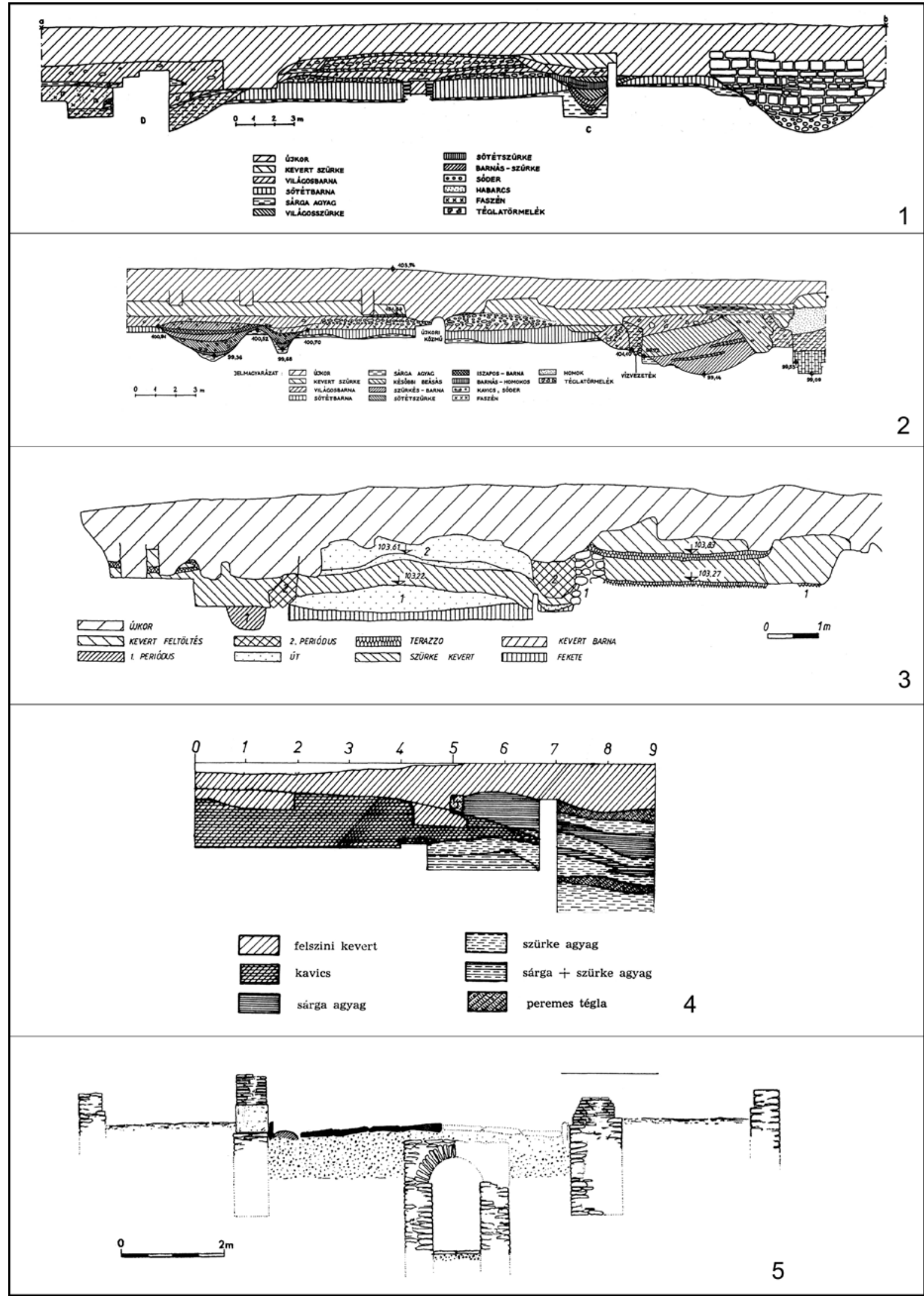

11. kép. Római kori útmetszetek Magyarország területéről. 1: Aquincum-északkeleti táborsarok (NéMETH 1976, 12. ábra nyomán); 2: Aquincum, a tábor déli frontja (KéRDŐ 1976, 16. ábra nyomán); 3: Aquincum, a tábor délkeleti negyede (KÉRDŐ 1997, 272, 3. kép nyomán); 4: Szombathely (Buócz 1971-1972, 205, 4. kép); 5: Szombathely (Kiss-SoszTARics 1996-1997, 111, Abb. 4. nyomán)

Fig. 11. Sections of Roman age roads in Hungary. 1-3: Aquincum (after NÉMETH 1976, Fig. 12; KéRDÓ 1976, Fig. 16; KÉRDÓ 1997, 272, Fig. 3); 4-5: Szombathely (after BuÓcz 1971-1972, 205, Abb. 4; KIss-SOSZTARICs 1996-1997, 111, Abb. 4) 


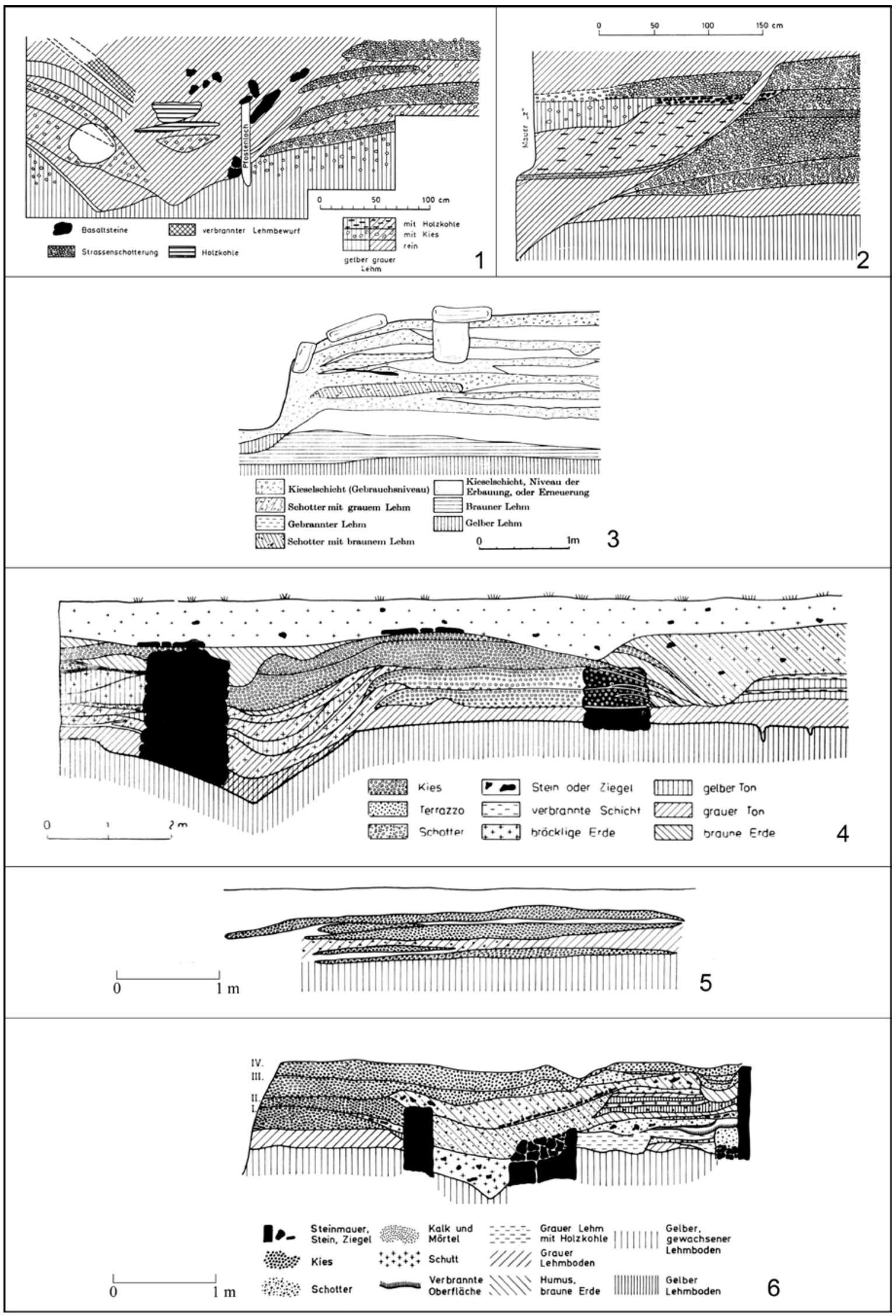

12. kép. 1-6: Zalalövő (RFiZ 1975, 217, Abb. 8.; RFiZ 1975, 218, Abb. 10; RFiZ 1982-1983, 416, Abb. 13; RFiZ 1978-1979, 286, Abb. 20; RFiZ 1977, 371, Abb. 21; RFiZ 1977, 367, Abb. 13 nyomán)

Fig. 12. 1-6: Zalalövő (after RFiZ 1975, 217, Abb. 8. and 218, Abb. 10; RFiZ 1982-1983, 416, Abb. 13; RFiZ 1978-1979, 286, Abb. 20; RFiZ 1977, 371, Abb. 21 and 367, Abb. 13) 
ritkán, vagy egy Direktortól, a' ki még ritkábban, vagy sohase is értik $a^{\prime}$ dolgot és tudatlanságok által mind $a^{\prime}$ Domestikát, mind a' szegény népet rettenetessen megkárosítják - fügjön."94

$\mathrm{Az}$ írásos források alapján biztosak lehetünk abban, hogy Érden a római kori limesút vonalán egy újkori út is épült. Mivel az ásatás során nem volt megfigyelhető több periódus, és nem lelhető fel sem a római kori utak, sem az újkori felmérések között olyan metszet, amely az érdi útéhoz hasonló szerkezetet mutatna, a feltárt útrészlet korát továbbra sem tartom meghatározhatónak. Figyelembe véve azt a sztratigráfiai alapelvet, hogy a későbbi jelenségek magasabban vannak, újragondolandónak vélem azoknak a felszínen, illetve légi fotón érzékelhető útnyomoknak a da-
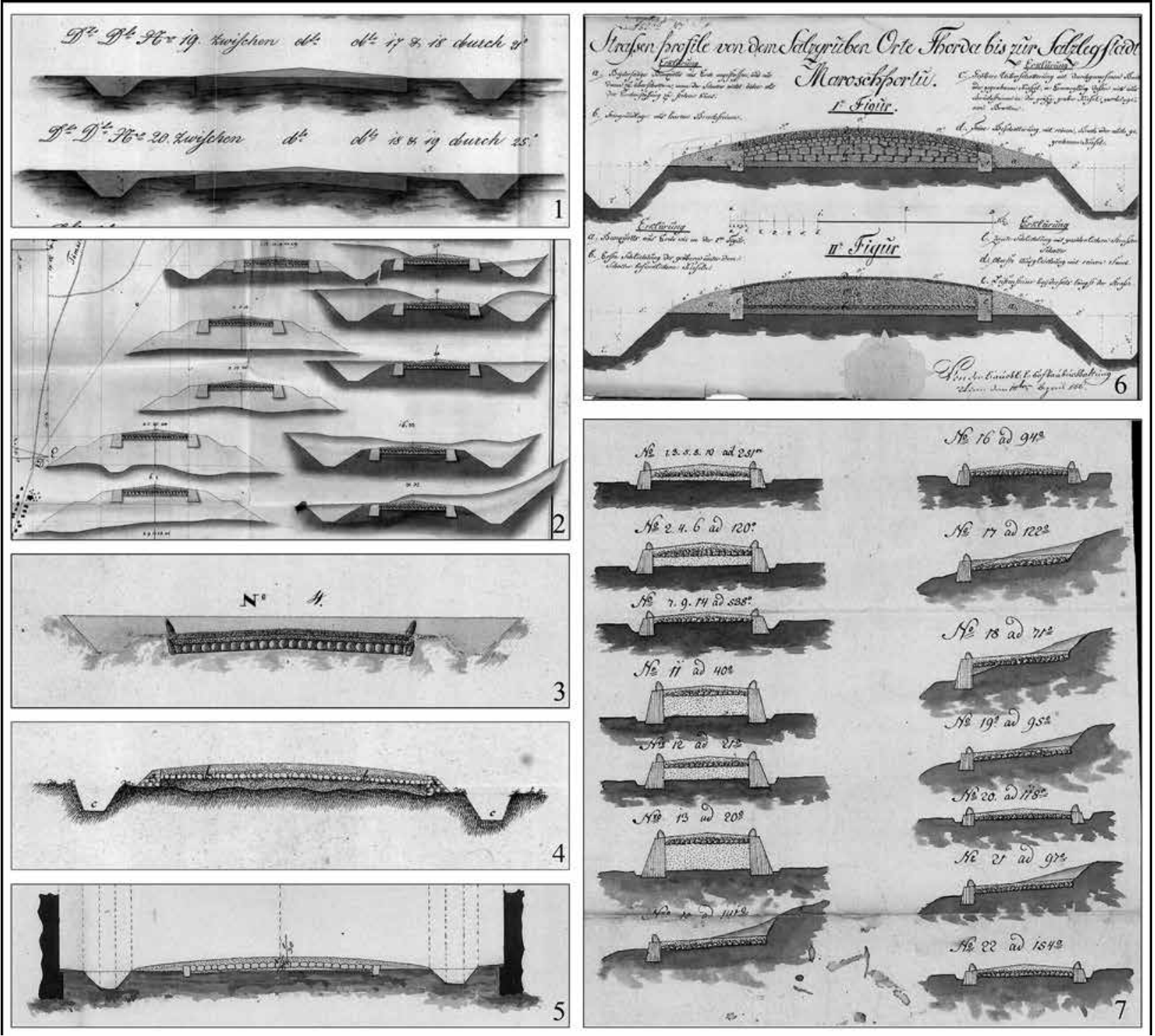

13. kép. Újkori útmetszetek. 1: Újvidék (MNL OL S 11, No. 1415/2, részlet); 2: Szilágy megye (MNL OL S 105, No. 18, részlet); 3: Hatvan (PML XV. 6. (PMT) 5/8, részlet); 4: Huszt (MNL OL S 12 Div. XIII. No. 0111/2); 5: Miskolc (MNL OL S 101, No. 24, részlet); 6-7: Szilágy megye (MNL OL S 105, No. 17 és 19, részlet)

Fig 13. Sections of roads built in the 19th century. 1: Novi Sad (MNL OL S 11, No. 1415/2, detail); 2: Szilágy County (MNL OL S 105, No. 18, detail); 3: Hatvan (PML XV. 6. (PMT) 5/8, detail); 4: Huszt (MNL OL S 12 Div. XIII, No. 0111/2); 5: Miskolc (MNL OL S 101, No. 24, detail); 6-7: Szilágy County (MNL OL S 105, No. 17 and 19, detail) 
tálását is, ahol a római kori nyomvonalon újkori út is létesült. Ilyenek Mosonmagyaróvár-Istvánpuszta (Izabella-major), ${ }^{95}$ Gönyú, ${ }^{96}$ SzentendreKözép-dúlő, ${ }^{97}$ Budakalász-Dunai-Kisföldek, ${ }^{98}$ Ercsi, ${ }^{99}$ Dunaújváros ${ }^{100}$ és Paks, ${ }^{101}$ de idetartozhat a nemrégiben Budapest-Nagytétényben feltárt két útszakasz is. ${ }^{102}$

\section{Rövidítések}

$\begin{array}{ll}\text { CIL } & \text { Corpus Inscriptionum Latinarum } \\ \text { FML } & \text { Fejér Megyei Levéltár }\end{array}$

MNL OL Magyar Nemzeti Levéltár Országos Levéltára

OSZK Országos Széchényi Könyvtár

PML Pest Megyei Levéltár

\section{IRODALOM}

BAKÁCS ISTVÁN

1982 Iratok Pest megye történetéhez 1002-1437. Pest Megye Múltjából 5. Budapest.

BENDEFY LÁSZLÓ

1976 Mikoviny Sámuel megyei térképei különös tekintettel az Akadémiai Könyvtár kézirattárának Mikovinytérképeire. A Magyar Tudományos Akadémia Könyvtárának Kiadványai 76. Budapest.

BESZÉDEs JÓZSEF-KoZMA AdrIENNE-SZILAs GÁBOR-Terei GYÖRGY

2012 Régészeti munkák a Budapest-Tárnok vasútvonal felújításának fővárosi szakaszán 2011-2012-ben (Archaeological work in the Budapest section of the reconstruction of the Budapest-Tárnok railroad in 2011-2012). Aquincumi Füzetek (Budapest) 19, 89-107.

BÉl MÁTYÁS

1977a Fejér vármegye leírása. Fejér Megyei Történeti Évkönyv (Székesfehérvár) 11, 83-117.

1977b Pest megyéról. Pest Megyei Múzeumi Füzetek 10. Szentendre.

BONFINI, ANTONIO

1936 Rerum Ungaricarum decades. Tomus I. Decas I. Bibliotheca scriptorum medii recentisque aevorum. Lipsiae.

P. BUÓCZ TERÉZIA

1971-1972 Savaria úthálózatának kronológiája a Járdányi Paulovics István Romkertben. Savaria (Szombathely) 5-6, 201-215.

CZAGa ViKTÓRIA-GARBÓcZi LÁSZló-SZABÓ CSABA

2002 Dokumentumok Budafok-Tétény történetéhez 1731-1950. Budapest.

CSERMÉNYI, VAJK-TÓTH, Endre

1979-1980 Eine römische Strassenstation und die Strassenstrecke zwischen Salla und Arrabona (Római őrállomás és a Borostyánkő-út a Zala és a Rába folyók között). Savaria (Szombathely) 13-14, 171-203.

FÉNYES ELEK

1847 Magyarország leirása. II. rész. Pest.

1851 Magyarország geographiai szótára. I. kötet. Pest.

GABLER, DÉNES

1991 Römische Strassenstation in der Gemarkung von Sárvár. Communicationes Archaeologicae Hungariae (Budapest) 39-84.

95 VisY 2011, 55., 37. kép. Az újkori út a harmadik katonai felmérés 1:75 000 méretarányú Zone 14 Colonne XVI-XVII (48584859) szelvényén látható.

${ }^{6}$ VIsY 2000, 21., 17. ábra. Az újkori út a harmadik katonai felmérés 1:75 000 méretarányú Zone 15 Colonne XX (4962) szelvényén látható.

97 MRT 7, 286., 28/29. lelőhely. Az újkori út az első katonai felmérés Colonne XIV Sectio XIX, a második katonai felmérés Colonne XXXII, Sectio 19 és a harmadik katonai felmérés 1:75000 méretarányú Zone 15 Colonne XX (4962) szelvényein is látható.

${ }^{98}$ MRT 7, 48, 3/11. lelóhely. Az újkori út az első katonai felmérés Colonne XIV, Sectio XIX, a második katonai felmérés Colonne XXXII, Sectio 19 és a harmadik katonai felmérés 1:75000 méretarányú Zone 15 Colonne XX (4962) szelvényein is látható.

99 VIsY 2000, 63-65., 90-93. ábra. Az újkori út a második katonai felmérés Colonne XXXI, Sectio 53 szelvényén látható.

100 VISY 2011, 101., 101. kép. Az újkori út a második katonai felmérés Colonne XXXII, Sectio 55-56 szelvényein látható. VISY
1978, 247., 12. kép és Visy 1980, 166., 1. kép. „A" út megfelel az első katonai felmérés Colonne XIII, Sectio XXV-XXVI szelvényein látható útvonalnak.

101 VISY 2000, 87., 137. ábra. Az újkori út a harmadik katonai felmérés 1:75000 méretarányú Zone 19 Colonne XIX (5361) szelvényén látható.

102 SZILAS-VIRÁG-BeSZÉDES 2010, 88., 1. kép, 95., 7. kép, 96-100. és Beszédes-Kozma-SzILAS-Terei 2012, 103-106, 8. lelőhely, 9. kép. Ezzel a két útszakasszal párhuzamosan, de a Dunához közelebb futó útszakaszt az ásató (SzIRMAI 1984, 157) szintén a limesúttal azonosította, ami ellentmondás. Az út rétegződése - a szegélykövek között tört kő, ezen döngölt kavicsos homok - megfelel az idézett újkori útmetszeteknek. Az első katonai felmérés Colonne 13-14, Sectio 14 szelvényei és a második katonai felmérés Colonne XXXII, Sectio 51 szelvénye alapján arra gondolhatunk, hogy a vasútvonalak megépítését követő útkorrekciók során került használaton kívül a két feltárt útszakasz. CZAGA-GARBócZI-SZABó 2002, 137-138, 37. dokumentum alapján az utat 1897-ben emelték a mai töltés szintjére. 
GÁLl IMRE

1970 Régi magyar hidak. Budapest.

GYÖRFFY GYÖRGY

1998 Az Árpád-kori Magyarország történeti földrajza 4. Budapest.

HERMANN EGYED

1943 Budáról Belgrádba 1663-ban. Ottendorff Henrik képes útleírása. Tolna Vármegye Múltjából 7. Pécs.

HoRVÁtH ÉvA

1981-1982 A hazai postai járatok és jármúveik a 18-19. században, a korabeli szakirodalom tükrében. A Közlekedési Múzeum Évkönyve (Budapest) 6, 183-208.

ISTVÁNFFY MIKLÓS

2001 Magyarok dolgairól írt históriája. Tállyai Pál XVII. századi fordításában. Történelmi Források I/1. Budapest.

KÁROLY JÁNOS

1896 Fejér vármegye története. I. kötet. Székesfejérvár.

1901 Fejér vármegye története. IV. kötet. Székesfejérvár.

H. KELEMEN MÁRTA

1992 A Brigetio-Aquincum közötti római út Süttő-Piliscsév közötti szakasza. In: Solymosi L.-Somfai B. (szerk.): A Dunántúl településtörténete 9. Veszprém, 23-26.

KERESKÉNYI GYULA

1874 Érd (Hamzsabég) és Batta (Százhalom) községek történeti vázlata. Székesfejérvár.

H. KÉRDÓ KATALIN

1976 Előzetes jelentés az aquincumi II-III. századi legiostábor déli, valamint a IV. századi erőd nyugati frontján végzett kutatásokról (Preliminary Report on the Investigations Conducted at the Southern Front of the 2-3rd Century Legionary Camp and at the Southern Front of the 4th Century Fort of Aquincum). Budapest Régiségei (Budapest) 24/1,71-77.

1997 Kutatások az aquincumi 2-3. századi legiostábor retenturájának északi részén. Budapest Régiségei (Budapest) 31, 269-272.

Kiss, PÉTER- SOSZTARICS, OTTÓ

1996-1997 Ein besonderer Meilenstein aus Savaria. Savaria (Szombathely) 23/3, 101-113.

KOVÁCS, PÉTER

1999 Vicus és castellum kapcsolata az alsó-pannoniai limes mentén. Studia Classica 1. Piliscsaba.

2000 Matrica. Excavations in the Roman Fort at Százhalombatta (1993-1997). Studia Classica 3. Budapest.

2007 Római kor - Limes- és helyőrségtörténet Pest megyében. In: Fancsalszky G. (szerk.): Pest megye monográfiája. I. kötet 1. rész. A kezdetektől a honfoglalásig. Pest megye régészeti emlékei. Budapest, 211-248.

LÁNG, ORSOLYA

2005 New Data Concerning the Diagonal Road between Aquincum and Brigetio. In: Visy, Zs. (ed.): Limes XIX. Proceedings of the XIXth International Congress of Roman Frontier Studies held in Pécs, Hungary, September 2003. Pécs, 657-666.

LUCZENBACHER JÁNOS

1847 A’ pogány magyar sírok körül tett fölfedezései. Magyar Academiai Értesítő (Pest) 7, 282-289.

MÓCSY ANDRÁS

1955 Aszázhalombatta-dunafüredi római tábor és település (Roman Camp and Settlement at Százhalombatta). Archaeologiai Értesítő (Budapest) 82, 59-69.

MrÁv ZsOLT

2000 Érd, Ófalu, római vagy mély út. In: Kisfaludi J. (szerk.): Régészeti Kutatások Magyarországon, 2000. Budapest 2003, 134

MRT 5

1979 Horváth István-H. Kelemen Márta-Torma István: Komárom megye régészeti topográfiája. Esztergom és a dorogi járás. Magyarország régészeti topográfiája 5. Torma I. szerk. Budapest.

MRT 7

1986 Dinnyés István-Kővári Klára-Lovag Zsuzsa-Tettamanti Sarolta-Topál Judit-Torma István: Pest megye régészeti topográfiája. A budai és szentendrei járás. Magyarország régészeti topográfiája 7. Torma I. szerk. Budapest.

NAGY LAJOS

1972 Adatok Fejér megye történeti-földrajzi névanyagához (Angaben zum historisch-geographischen Namensmaterial im Komitat Fejér). Fejér Megyei Történeti Évkönyv (Székesfehérvár) 6, 227-313.

NÉMETH MARGIT

1976 Régészeti megfigyelések az észak-keleti táborsaroknál. Előzetes jelentés (Archaeological Observations near the North-Eastern Corner of the Camp. Preliminary Report). Budapest Régiségei (Budapest) 24/1, 61-69. 


\section{OLÁH MiKLÓS}

1938 Hungaria - Athila. Bibliotheca scriptorum medii recentisque aevorum. Budapest.

K. PALÁgyi SyLVIA

1992 Adatok a Savariából Arrabonába vezető római út kemenesszentpéteri szakaszának kutatásához.

In: Solymosi L.-Somfai B. (szerk.), A Dunántúl településtörténete IX. Veszprém, 27-34.

PAULOVICS IstVÁN

1927 A dunapentelei római telep (Intercisa). Archaeologia Hungarica 2. Budapest.

1957 Nagytétényi kutatások. Régészeti Füzetek I:3. Budapest.

PESTY FRIGYeS

1864 Pesty Frigyes helységnévtára, Fejér megye. Fejér Megyei Történeti Évkönyv (Székesfehérvár) 11, 161305.

POLGÁR IVÁN

1932 Fejérmegye római mérföldkövei. Székesfehérvári Szemle (Székesfehérvár) 2, 6-10.

RAISZ KÁROLY

1823 Az Útaknak elmés igazgatásáról egy szó. Tudományos Gyújtemény (Pest) 7/5, 19-43.

REDŐ, FERENC

2005 The Kerka Valley in the Roman Age. Antaeus (Budapest) 28, 101-115.

RFiZ

1975 Römische Forschungen in Zalalövő 1975. Acta Archaeologica Academiae Scientiarum Hungaricae (Budapest) 29, 209-279.

1976 Römische Forschungen in Zalalövő 1976. Acta Archaeologica Academiae Scientiarum Hungaricae (Budapest) 30, 350-430.

1977 Römische Forschungen in Zalalövő 1977. Acta Archaeologica Academiae Scientiarum Hungaricae (Budapest) 31, 357-390.

1978-1979 Römische Forschungen in Zalalövő 1978-1979. Acta Archaeologica Academiae Scientiarum Hungaricae (Budapest) 33, 273-346.

1982-1983 Römische Forschungen in Zalalövő 1982-1983. Acta Archaeologica Academiae Scientiarum Hungaricae (Budapest) 41, 405-433.

RÓMER, FLÓRIS

jkv. Rómer Flóris jegyzőkönyvei. Kézirat, Forster Gyula Nemzeti Örökségvédelmi és Vagyongazdálkodási Központ Tervtár.

1878 Résultats généraux du mouvement archéologique en Hongrie. Congrès international d'anthropologie et d'archéologie préhistoriques. Compte-rendu de la huitième session à Budapest 1876. Second volume. I. partie. Budapest.

SEIDL, JOHANN GABRIEL

1853 Beiträge zu einer Chronik der archäologischen Funde in der österreichischen Monarchie. Archiv für Kunde Österreichischer Geschichts-Quellen (Wien) 9, 81-168.

SRH

1999 Scriptores rerum Hungaricarum tempore ducum regumque stirpis Arpadianae getarum. Vol. I-II. Budapest.

SZABó Máté

2014 Római út Érd határában (Roman Road on the Confines of Érd). In: Rajna A. (szerk.): Múltunk a föld alatt. Újabb régészeti kutatások Pest megyében. Ferenczy Múzeum Kiadványai, A sorozat: Monográfiák 1. Szentendre, 87-93.

SZILAS GÁBOR-M. VIRÁG ZsUZSANNA-BESZÉDES JÓZSEF

2010 Középső újkőkori, késő avar telepnyomok és a limesút részlete az M0 autóút Budatétény-Növény utcai csomópontjának feltárásán (Middle Neolithic, late Avar settlement traces and a segment of the limes road from the excavation of the Budatétény-Növény Street junction of the M0 motorway). Aquincumi Füzetek (Budapest) 17, 87-111.

SZIRMAI KRISZTINA

1984 Beszámoló a budatétényi római kori telep feltárásáról. II. rész. 1974-1977 (Bericht über die Ausgrabung der römer Siedlung in Budatétény. II. Teil. 1974-1977). Budapest Régiségei (Budapest) 26, 153-182.

SZŐNYI ESZTER

1999 Római kori útadatok Győr megyében (Added Data to Ancient Roman Roads in Győr County). Arrabona (Győr) 37, 83-98.

THURÓCZY, JÁNOS

1985 Chronica Hungarorum. I. Textus. Bibliotheca scriptorum medii recentisque aevorum. Series nova. Tomus VII. Budapest.

VÁMOS GÁBOR

2000-2001 Növényjelenségek a Borostyánkő út magyarszecsődi szakaszán. Savaria (Szombathely) 25/3, 201-234. 


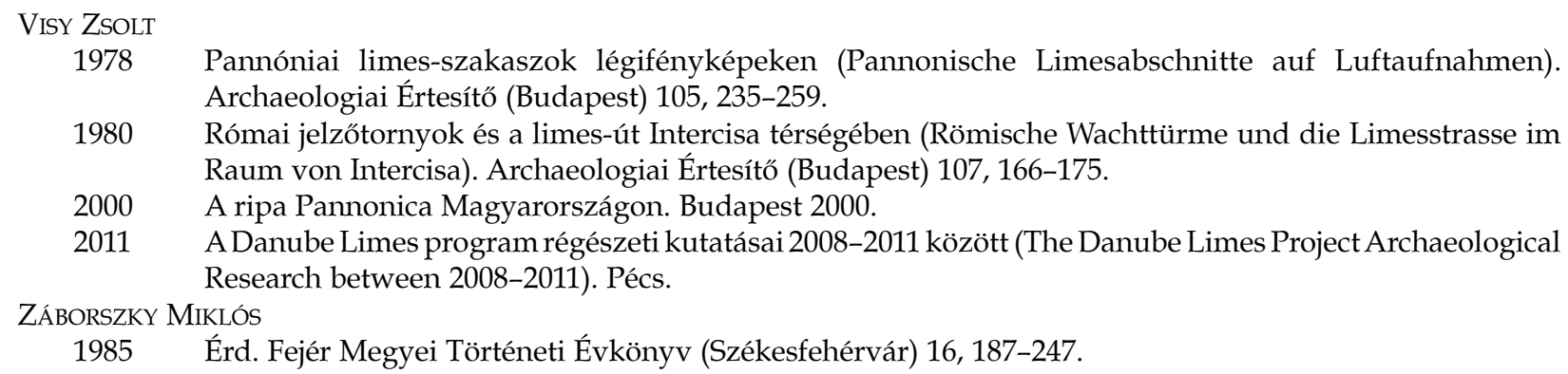

\title{
ROMAN ROAD ON THE CONFINES OF ÉRD
}

\author{
GÁBOR VARGA
}

Máté Szabó excavated the site of Érd, Római út (Roman Road) in 2012 and published his results in 2014 (SzABÓ 2014). He concluded that the excavated remains of the road can be dated to the Roman Age. I collected all the available former data of the site in order to examine this dating of the remains.

The history of the road can be drawn on the base of the sources and the archaeological literature as follows. The Roman age road was in function in the Middle Ages. Its condition became so weak until the first half of the 18th century that a new path came into use (Postal road).

This later mentioned road also decayed, so Fejér County suggested to build a new road in the line of the Roman Road in 1814 (Fig. 6, 1-2). The section of the new road in Érd was finished in 1818. Because other sections of the road lay in the floodplain of the Danube, a new road was built again before 1837 . Today this later one is the main road Nr. 6 .

Archaeologists investigated the site first in 1847. The first who mentioned the pavement of the road was Floris Rómer in 1867. It is possible that ten or twenty-seven years after the abandonment of the road its pavement built in 1818 was misinterpreted as a Roman Age one.

The only one who investigated and published the layers of the road is Máté Szabó. The base of the road was dug into the subsoil. It is soil mixed with lime. On both sides of the base there are edges of the road which are made of stone and gravel. The space between the edges is filled with gravel. On the gravel there was a band of loess and a recent burnt layer. The road has one ditch on his east side. There are no traces of the renewal of the road.

Recent metal objects were found on the top of the gravel layer and in the burnt layer. In the east edge of the road metal objects of unknown age were found. One piece of Roman age boot nail was found in the ditch.

The excavated Roman age roads have a different structure (Fig. 9-12). The roads were built on the humus or the subsoil, but were never deepened into the surface. Several roads have no base, simply consist of one beaten gravel layer. If there is a base of the road, it was made of sand or stone, but never of soil mixed with lime. The edge of the road is also unique. Carved stones used as a curb appear only in paved roads, which were built only in some built-in area of the towns and forts.

The roads built in the 19th century also differ from the one excavated in Érd. Only a few of them have a deepened base, the edges involve the base and the base are made of stone (Fig. 13).

On the base of the sources it is clear that on the path of the Roman road a new road was built in the 19th century. Because the excavated road has a single phase and its structure suits neither Roman age nor recent structures, I think that we still have to be dubious in the dating of the pavement of the "Roman road" of Érd. 